\title{
Acid-Sensing Ion Channels Activated by Evoked Released Protons Modulate Synaptic Transmission at the Mouse Calyx of Held Synapse
}

\author{
Carlota González-Inchauspe, ๑Francisco J. Urbano, @Mariano N. Di Guilmi, and @ Osvaldo D. Uchitel \\ Instituto de Fisiología, Biología molecular y Neurociencias, Departamento de Fisiología, Biología Molecular y Celular “Dr. Héctor Maldonado," Facultad de \\ Ciencias Exactas y Naturales, Universidad de Buenos Aires, Ciudad Universitaria, Ciudad Autónoma de Buenos Aires, Beunos Aires, CP 1428 EGA \\ Argentina
}

Acid-sensing ion channels (ASICs) regulate synaptic activities and play important roles in neurodegenerative diseases. We found that these channels can be activated in neurons of the medial nucleus of the trapezoid body (MNTB) of the auditory system in the CNS. A drop in extracellular $\mathrm{pH}$ induces transient inward ASIC currents $\left(\mathrm{I}_{\mathrm{ASIC}} \mathrm{s}\right)$ in postsynaptic MNTB neurons from wild-type mice. The inhibition of $\mathrm{I}_{\mathrm{ASIC}} \mathrm{s}$ by psalmotoxin-1 (PcTx1) and the absence of these currents in knock-out mice for ASIC-1a subunit (ASIC1a ${ }^{-/-}$) suggest that homomeric ASIC-1as are mediating these currents in MNTB neurons. Furthermore, we detect ASIC1a-dependent currents during synaptic transmission, suggesting an acidification of the synaptic cleft due to the corelease of neurotransmitter and $\mathrm{H}^{+}$from synaptic vesicles. These currents are capable of eliciting action potentials in the absence of glutamatergic currents. A significant characteristic of these homomeric ASIC-1as is their permeability to $\mathrm{Ca}^{2+}$. Activation of ASIC-1a in MNTB neurons by exogenous $\mathrm{H}^{+}$induces an increase in intracellular $\mathrm{Ca}^{2+}$. Furthermore, the activation of postsynaptic ASIC-1as during high-frequency stimulation (HFS) of the presynaptic nerve terminal leads to a PcTx1-sensitive increase in intracellular $\mathrm{Ca}^{2+}$ in MNTB neurons, which is independent of glutamate receptors and is absent in neurons from ASIC1a ${ }^{-1-}$ mice. During HFS, the lack of functional ASICs in synaptic transmission results in an enhanced short-term depression of glutamatergic EPSCs. These results strongly support the hypothesis of protons as neurotransmitters and demonstrate that presynaptic released protons modulate synaptic transmission by activating ASIC-1as at the calyx of Held-MNTB synapse.

Key words: ASIC-1a; calyx of Held; glutamatergic EPSCs; protons; short-term depression; synaptic plasticity

\section{Significance Statement}

The manuscript demonstrates that postsynaptic neurons of the medial nucleus of the trapezoid body at the mouse calyx of Held synapse express functional homomeric Acid-sensing ion channel-1a (ASIC-1as) that can be activated by protons (coreleased with neurotransmitter from acidified synaptic vesicles). These ASIC-1as contribute to the generation of postsynaptic currents and, more relevant, to calcium influx, which could be involved in the modulation of presynaptic transmitter release. Inhibition or deletion of ASIC-1a leads to enhanced short-term depression, demonstrating that they are concerned with short-term plasticity of the synapse. ASICs represent a widespread communication system with unique properties. We expect that our experiments will have an impact in the neurobiology field and will spread in areas related to neuronal plasticity.

\section{Introduction}

Extracellular proton concentration in brain fluctuates in both physiological and disease conditions (Chesler, 2003). Increase in proton concentration or reduction in $\mathrm{pH}$ activate acid-sensing ion channels (ASICs; Waldmann et al., 1997a,b; Krishtal, 2003; Wemmie et al., 2006), which are part of the larger amiloride- 
sensitive degenerin/epithelial $\mathrm{Na}^{+}$channel family (Kellenberger and Schild, 2015). ASICs play an important function in physiologic processes and signal transduction associated with local and global extracellular $\mathrm{pH}$ variations during normal and pathological neuronal activity. ASICs are engaged in synaptic transmission contributing to plasticity, learning, memory, and fear responses (Wemmie et al., 2002, 2006; Chu and Xiong, 2012; Huang et al., 2015). They have also been implicated in pathological conditions, including ischemic stroke (Chu and Xiong, 2012; Xiong et al., 2004; Yermolaieva et al., 2004), epileptic seizure (Ziemann et al., 2008), multiple sclerosis, and autoimmune encephalomyelitis (Friese et al., 2007).

Six different ASIC subunits, encoded by four genes, have been cloned (Kellenberger and Schild, 2015), forming homomultimeric and heteromultimeric channel complexes that vary in their expression within organs and are activated at different $\mathrm{pH}$ values (Krishtal, 2003; Lingueglia et al., 1997; Wemmie et al., 2003; Gründer and Pusch, 2015). ASIC-1a, ASIC-2a, and ASIC-2b are expressed in brain neurons with particularly high abundance in the cerebral cortex, hippocampus, basal ganglia, amygdala, olfactory bulb, and cerebellum (Krishtal, 2003; Chen et al., 1998; Waldmann and Lazdunski, 1998; Price et al., 2014). The subunit ASIC-1a forms heteromeric channels with ASIC-2a, and also $\mathrm{Ca}^{2+}$-permeable homomeric channels (Xiong et al., 2004; Yermolaieva et al., 2004; Lingueglia et al., 1997; Waldmann et al., 1997a,b; Wu et al., 2004). ASIC-1a is enriched in synaptosomal fractions, which are expressed in dendritic spines (HruskaHageman et al., 2002; Wemmie et al., 2002), where channels interacts with the postsynaptic scaffolding proteins like PSD-95 and PICK1 (protein interacting with C kinase 1) and also with NMDA receptors and voltage-gated $\mathrm{Ca}^{2+}$ channels (Zha, 2013).

ASICs contribute to modulate synaptic transmission (Huang et al., 2015). ASIC-1a disruption increased miniature EPSC frequencies and reduced paired-pulse ratios in microisland cultures of hippocampal neurons (Cho and Askwith, 2008), impaired hippocampal long-term potentiation (Wemmie et al., 2002), and potentiated neuromuscular transmission (Urbano et al., 2014), suggesting that ASIC activation affects presynaptic release probability.

It is known that synaptic vesicles are acidic, and it is postulated that acidification of the synaptic cleft during neurotransmission might activate ASICs (Palmer et al., 2003; Hnasko and Edwards, 2012). Two studies have shown that ASICs contribute to EPSCs in both the lateral amygdala (Du et al., 2014) and nucleus accumbens core (Kreple et al., 2014), strongly supporting the concept that protons coreleased with neurotransmitters might activate ASICs.

In the present work, we sought to clarify the functional significance of proton-ASIC signaling and the role of ASIC-1a during high-frequency stimulation (HFS) of synaptic transmission at the calyx of Held-medial nucleus of the trapezoid body (MNTB) synapse by examining the effects of ASIC- 1 a on electrical and $\mathrm{Ca}^{2+}$ postsynaptic signals and on the modulation of presynaptic quantal release of neurotransmitter.

Inward ASIC currents $\left(\mathrm{I}_{\mathrm{ASIC}} \mathrm{s}\right)$ sensitive to amiloride and to the specific ASIC-1a blocker psalmotoxin were elicited in the MNTB postsynaptic neurons but not in the presynaptic nerve terminal from wild-type (WT) mice. In contrast, $\mathrm{I}_{\mathrm{ASIC}} \mathrm{s}$ were $\mathrm{ab}$ sent in the ASICla ${ }^{-1-}$ mouse. ASIC-1a currents evoked by exogenous $\mathrm{H}^{+}$induced an increase in intracellular calcium $\left(\mathrm{Ca}^{2+}{ }_{\mathrm{i}}\right)$ in postsynaptic MNTB neurons. In addition, under physiological $\mathrm{pH}$ and pharmacological blockade of glutamate, GABA and glycine postsynaptic receptors, presynaptic stimulation-generated small $\mathrm{I}_{\mathrm{ASIC}} \mathrm{S}$, and HFS induced an increase in $\mathrm{Ca}^{2+}{ }_{\mathrm{i}}$, which can be attributed to the activation of postsynaptic ASIC-1 as due to acidification of the synaptic clef. Pharmacological blockage or ablation of ASIC-1as enhanced short-term depression (STD) of glutamatergic EPSCs. These results demonstrate that presynaptic released protons activate postsynaptic ASIC-1as and modulate synaptic transmission at the calyx of Held-MNTB synapse. To our knowledge, this is the first report of an ASIC-dependent postsynaptic $\mathrm{Ca}^{2+}$ signal triggered by evoked presynaptic released protons in the CNS, suggesting that protons as cotransmitters are relevant for information processing.

\section{Materials and Methods}

\section{Animal model and preparation of brainstem slices}

ASICla ${ }^{-1-}$ mice (generated using mice of the C57BL/6 genetic background) were provided by the laboratory of Dr. John A. Wemmie (University of Iowa, Iowa City, IA) and were kept in the animal facility of the Faculty of Exact and Natural Sciences (University of Buenos Aires, Buenos Aires, Argentina). All experiments involving mice were performed according to national guidelines and were approved by local ethical committees.

Mice of either sex were killed by decapitation on postnatal day 13 (P13) to P18, and the brain was removed and placed into ice-cold lowsodium artificial CSF (aCSF). The brainstem was mounted in the Peltier chamber of an Integraslice 7550PSDS vibrating microslicer (Campden Instruments). Transverse slices of $300 \mu \mathrm{m}$ thickness were cut in low sodium aCSF $\left(\mathrm{NaCl}\right.$ replaced by $250 \mathrm{~mm}$ sucrose, $2.9 \mathrm{~mm} \mathrm{MgCl}_{2}$, and 0.1 $\mathrm{mm} \mathrm{CaCl} 2$ ) and then transferred to an incubation chamber containing normal bicarbonate aCSF with low calcium $\left(0.1 \mathrm{~mm} \mathrm{CaCl}_{2}\right.$ and $2.9 \mathrm{~mm}$ $\mathrm{MgCl}_{2}$ ) at $37^{\circ} \mathrm{C}$ for $1 \mathrm{~h}$. Recordings were obtained in normal bicarbonate aCSF containing the following (in $\mathrm{mm}$ ): $\mathrm{NaCl} 125, \mathrm{KCl} 2.5, \mathrm{NaHCO}_{3} 26$, $\mathrm{NaH}_{2} \mathrm{PO}_{4} 1.25$, glucose 10 , ascorbic acid 0.5 , myoinositol 3, sodium pyruvate $2, \mathrm{MgCl}_{2} 1$, and $\mathrm{CaCl}_{2}$ 2. The $\mathrm{pH}$ was 7.3 when gassed with $95 \%$ $\mathrm{O}_{2}-5 \% \mathrm{CO}_{2}$.

\section{Electrophysiology recordings}

$\mathrm{H}^{+}$-gated, ASIC-mediated currents (i.e., $\mathrm{I}_{\mathrm{ASIC}} \mathrm{s}$ ) and glutamatergic EPSCs on MNTB neurons were measured using whole-cell voltage clamp. Neurons were visualized using Nomarski optics on a BX50WI (Olympus) microscope, with a $40 \times / 0.90$ numerical aperture waterimmersion objective lens (LUMPlane FI, Olympus).

To measure $\mathrm{I}_{\mathrm{ASIC}} \mathrm{S}$, slices were transferred to a recording chamber perfused with an extracellular HEPES/MES-based solution at $\mathrm{pH} 7.3$, containing the following (in $\mathrm{mm}$ ): $\mathrm{NaCl} 128, \mathrm{KCl} 2.5, \mathrm{CaCl}_{2} 2, \mathrm{MgCl}_{2} 1$, glucose 15, sucrose 15, HEPES 5, MES 5, ascorbic acid 0.5, myoinositol 3, and sodium pyruvate 2. A HEPES buffering range of 6.8-8.2 allowed us to control recording solutions with a $\mathrm{pH}$ of $\sim 7.3$ while the MES buffering range of 5.5-6.7 allowed us to fix $\mathrm{pH} 5.5$ and 6.0 used during local pressure applications.

For recording EPSCs at the calyx of Held synapse, normal bicarbonatebased aCSF at pH 7.3 was used, unless in those experiments where perfusing with HEPES/MES-based aCSF of different $\mathrm{pH}$ buffer capacity is indicated (low vs high physiological buffering at $\mathrm{pH}$ 7.3: 1 and $10 \mathrm{~mm}$ HEPES, respectively).

Patch pipettes were pulled from borosilicate glass (Harvard Apparatus, GC150F-15, UK). Electrodes had resistances of 2.9-3.2 M $\Omega$ when filled with internal solution of the following composition ( $\mathrm{mM}$ ): $\mathrm{CsCl}$ 110, HEPES 40, TEA-Cl 10, $\mathrm{Na}_{2}$ phosphocreatine 12, EGTA 0.5, MgATP 2, LiGTP 0.5, and $\mathrm{MgCl}_{2}$ 1. PH was adjusted to 7.3 with $\mathrm{CsOH}$. To block $\mathrm{Na}^{+}$currents and avoid postsynaptic action potentials (APs), $10 \mathrm{~mm}$ QX-314 was added to the pipette solution. In whole-cell configuration under current-clamp mode, patch solutions contained the following (mM): K-gluconate 110, $\mathrm{KCl} 30, \mathrm{HEPES} \mathrm{10,} \mathrm{Na-phosphocreatine} \mathrm{10,}$ EGTA 0.2, MgATP 2, LiGTP 0.5, and $\mathrm{MgCl}_{2} 1$.

Patch-clamp recordings were obtained using a Multiclamp 700B amplifier (Axon CNS, Molecular Devices), Digidata 1440A (Axon CNS, Molecular Devices), and pClamp 9.0 software. Data were sampled at 
a

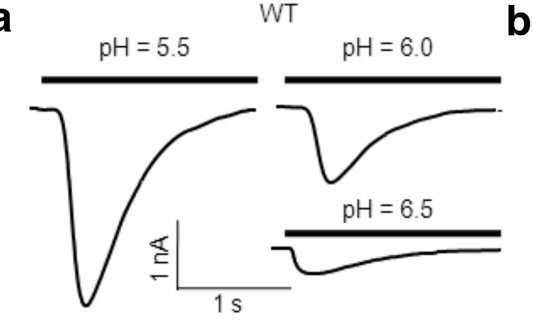

C

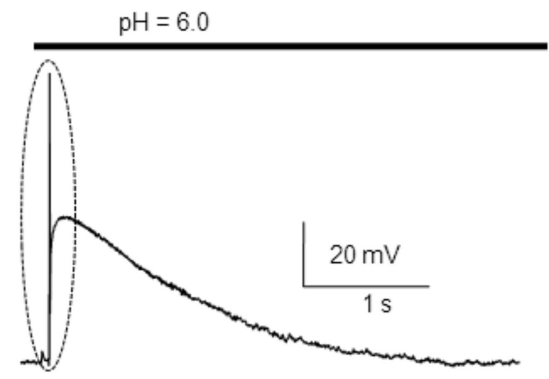

d

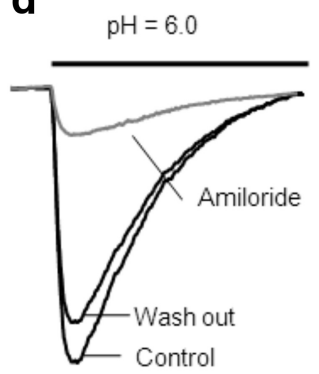

e b
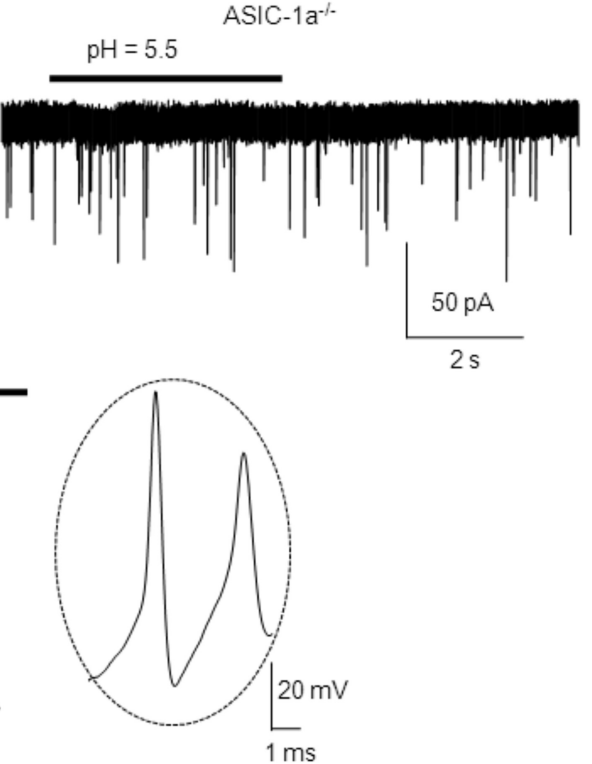

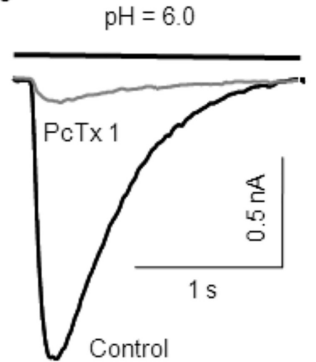

Figure 1. ASIC-1as are activated by a decrease of extracellular pH in MNTB neuron. $\boldsymbol{a}, \mathrm{H}^{+}$-gated $\mathrm{I}_{\mathrm{ASIC}} \mathrm{s}$ from MNTB neurons in WT mice during transient acidification (4s) of the extracellular media from $\mathrm{pH} 7.3$ to 5.5 (mean peak amplitude, $2.5 \pm 0.5 \mathrm{nA} ; n=$ 25), pH 6.0 (mean peak amplitude, $0.94 \pm 0.22 \mathrm{nA} ; n=20$ ), or pH 6.5 (mean peak amplitude, $0.32 \pm 0.04 \mathrm{nA} ; n=6$ ). MNTB neurons were whole-cell patch clamped at a holding potential of $-70 \mathrm{mV}$. $\boldsymbol{b}$, Acidification of the extracellular media induced no current in ASIC1a ${ }^{-1-}$ mice. Please note the different magnitude in the current calibration bar. $c$, Activation of ASICs by a drop in $\mathrm{pH}$ from 7.3 to 6.0 induced membrane depolarization and triggered action potentials (shown in an expanded timescale in the inset at the right) in MNTB neurons from WT mice. $\boldsymbol{d}$, In the presence of amiloride (150 $\mu \mathrm{M})$, a nonspecific ASIC blocker, the amplitudes of $\mathrm{ASIC}_{\mathrm{S}}$ triggered by dropping the $\mathrm{pH}$ from 7.4 to 6.0 were reduced in $82 \pm 4 \%$ in WT mice $(n=12)$. The effect was reversible after washout. $e$, Effect of PCTX1 (10 nM), a specific inhibitor of ASIC-1a homomers, on ASIC currents. The mean inhibition of I ASIC peak value $(n=7)$ was $90 \pm 3 \%$.

$50 \mathrm{kHz}$ and filtered at $6 \mathrm{kHz}$ (low-pass Bessel). Whole-cell membrane capacitances (15-25 pF) and series resistances (6-12 $\mathrm{M} \Omega$ ) were registered from the amplifier after compensation of the transient generated by a $10 \mathrm{~ms}$ voltage step and compensated by $50-60 \%$.

EPSCs were evoked by stimulating the globular bushy cell axons in the trapezoid body using a bipolar platinum electrode placed in the midline and applying square pulses $(0.1 \mathrm{~ms}$ and $4-10 \mathrm{~V})$ through an isolated constant-current stimulator (model DS3, Digitimer).

Proton $\left(\mathrm{H}^{+}\right)$-gated currents were evoked by local application of a puff with a duration of 3-4 s of a $10 \mathrm{~mm}$ MES-based aCSF solution at $\mathrm{pH}$ 5.5, 6.0 , or 6.5 using a micropipette (1.5-2 $\mathrm{M} \Omega$ resistance) connected to a Picrospritzer (Intracel). In a few experiments, $\mathrm{H}^{+}$iontophoresis was used to evoke ASIC currents. A micropipette $(>20 \mathrm{M} \Omega$ resistance) filled with $0.1 \mathrm{M} \mathrm{HCl}$ was connected to a Master-8 (A.M.P.I.) general purpose stimulator through a monopolar wire. Positive current pulses $(2 \mathrm{nA}, 3 \mathrm{~s}$ duration) were used to release $\mathrm{H}^{+}$from the pipette placed near the MNTB neurons.

Data analysis was performed using Clampfit 10.0 (Molecular Devices), and SigmaPlot 10.0, SigmaStat 3.5, and Excel 2003 (Microsoft). Data are expressed the average and were plotted as the mean \pm SEM. Statistical significance was determined using paired or unpaired Student's $t$ test or one-way repeated-measures ANOVA plus Student-Newman-Keuls post hoc test.
Psalmotoxin 1 (PcTx1) was purchased from Alomone Labs and lactic acid from Anedra.

\section{Fluorescence measurements}

For $\mathrm{Ca}^{2}$ image acquisition, we used a BX51WI upright microscope with a $60 \times$ objective lens (Olympus) and an electron multiplying CCD camera (Andor iXon, Oxford Instruments), together with cell $\wedge \mathrm{M}$ System Coordinator/ cell $\wedge \mathrm{R}$ real time controller software. MNTB neurons were loaded with the high-affinity $\mathrm{Ca}^{2+}$ indicator Fluo 8 in salt form, added to a final concentration of $100 \mu \mathrm{M}$ to the $\mathrm{CsCl}-$ based patch solution with no EGTA. The excitation and emission wavelengths were 488 and $515 \mathrm{~nm}$, respectively. Off-line image processing was performed using ImageJ. To analyze time-dependent fluorescence changes, we normalized mean fluorescence values as follows. First, the average $\mathrm{Ca}^{2+}$ fluorescence signal in a region of the cells was "background corrected" by subtraction of the average measured signal from an extracellular region. The backgroundcorrected fluorescence measured in each image frame during the protocol was then subtracted from the mean fluorescence measured in the first images acquired under initial control conditions $\left(F_{0}\right.$, line base before activating ASIC-1a) and finally normalized to $F_{0}$. This procedure subtracts autofluorescence and the present data as the Fluo 8 fluorescence $(\Delta F)$ normalized to basal fluorescence $\left(F_{0} ; \Delta F / F_{0}\right)$.

\section{Results}

Acid-sensing ion channels are proton receptors and generate inward currents in MNTB neurons

Local acidification induced $\mathrm{I}_{\mathrm{ASIC}} \mathrm{s}$ in MNTB neurons from WT mice (holding membrane potential, $-70 \mathrm{mV}$ ). On average, a $\mathrm{pH}$ drop from 7.3 to 5.5, 6.0, and 6.5 elicited $\mathrm{I}_{\mathrm{ASIC}} \mathrm{s}$ with peak amplitudes of $2.4 \pm 0.2 \mathrm{nA}$ $(n=25), 1.1 \pm 0.2 \mathrm{nA}(n=20)$, and $0.32 \pm$ $0.04 \mathrm{nA}(n=6)$ respectively, as shown in Figure $1 a$. As a control, application of a puff of $\mathrm{pH} 7.3$ solution did not induce any significant current (data not shown; $n=4$ MNTB neurons). Furthermore, extracellular application of a pH 5.5 or 6.0 solution did not evoke any current in neurons from ASICla ${ }^{-1-}$ mice $(n=3$ MNTB neurons; Fig. $1 b)$.

Under the same conditions as for postsynaptic neurons, we did not detect ASIC-mediated presynaptic currents when presynaptic terminals were patch clamped at $-70 \mathrm{mV}$ while applying an exogenous puff of either pH 5.5 or 6.0 extracellular solution $(n=12)$.

\section{ASIC activation depolarizes membrane potential, reaching action potential threshold in MNTB neurons}

Current-clamp experiments were conducted to record membrane potential in MNTB neurons during acidification. A drop in extracellular $\mathrm{pH}$ from 7.3 to 6.0 induced significant membrane depolarization from a resting membrane potential of -65 to -25 $\mathrm{mV}$ (Fig. $1 c ; n=3$ MNTB neurons), together with one or more action potentials (Fig. $1 c$, right). These results indicate that ASICs activation can contribute to the integration of excitatory inputs at MNTB neurons. 
Pharmacological profiles of $\mathrm{I}_{\mathrm{ASIC}} \mathrm{s}$ in MNTB neurons

Amiloride, a diuretic agent that inhibits $\mathrm{Na}^{+} / \mathrm{H}^{+}, \mathrm{Na}^{+} / \mathrm{Ca}^{2+}$ antiporters, and $\mathrm{ENaC}$, is a nonselective inhibitor for ASICs, which acts blocking their pore. At the MNTB neurons, amiloride $(150 \mu \mathrm{M})$ reduced the amplitudes of $\mathrm{I}_{\mathrm{ASIC}} \mathrm{S}$, in a reversible manner, to $82 \pm 4 \%$ in WT mice $(n=12)$ when $\mathrm{pH}$ was dropped from 7.3 to 6.0 (Fig. 1d). The spider peptide toxin PcTxl has been shown to specifically block homomeric ASIC-1as (Escoubas et al., 2000; Chen et al., 2006). In our experiments, $\mathrm{I}_{\mathrm{ASIC}} \mathrm{s}$ were almost abolished by PcTx1 (10 nM) in MNTB neurons from WT mice (Fig. $1 e ; n=7$ ). These data, together with the absence of acid-evoked currents in ASICla ${ }^{-/-}$mice suggest that ASICs in MNTB neurons are ASIC-1a homomers.

\section{Desensitization and recovery of ASIC-1a-mediated currents}

It has been reported that during maintained application (3-4 s) of a $\mathrm{pH}$ 6.0 solution, ASIC-1a-mediated currents inactivate ( $\mathrm{Li}$ et al., 2012). Inactivation was characterized by measuring the halfwidth (HW; at 50\% amplitude) and decaying time (DT; at $90-10 \%$ amplitude) of the currents evoked by application of a 4-s-long puff of $\mathrm{pH} 6.0$ solution. In WT mice, the mean $\mathrm{HW}$ of $\mathrm{I}_{\mathrm{ASIC}} \mathrm{S}$ was $678 \pm 50$ $\mathrm{ms}$, and the mean DT was $1.21 \pm 0.08 \mathrm{~s}$ $(n=20)$. Repetitive local acidifications desensitized ASIC-1a currents. Successive acidic pulses of $\mathrm{pH} 6.0$ solutions with a duration of $3 \mathrm{~s}$ were applied at $10 \mathrm{~s}$ intervals, eliciting transient ASIC-1a currents with progressively lower peak amplitudes (Fig. 2a). The time course of the successive $\mathrm{I}_{\mathrm{ASIC}}$ amplitudes (normalized to the peak amplitude of the first $\mathrm{I}_{\text {ASIC }}$ ) was well fitted to a single exponential decay function (Fig. $2 b ; n=6$ ).

To study the recovery of $\mathrm{I}_{\text {ASIC }}$ from desensitization, we used three consecutive $3 \mathrm{~s}$ duration acidic pulses to $\mathrm{pH} 6.0$ at $10 \mathrm{~s}$ intervals, followed by a $3 \mathrm{~s}$ duration acidic test pulse separated by different time intervals (representative traces in Fig. 2c). Recovery was calculated as the ratio between the $\mathrm{I}_{\mathrm{ASIC}}$ amplitudes of the test pulse and the first pulse before desensitization. Recovery as a function of time was best fitted by a sigmoid function with a time for half recovery of $39.5 \pm 0.7 \mathrm{~s}$ (Fig. $2 d ; n=6$ ).

\section{Current-voltage relationship of ASIC-1a currents in MNTB neurons}

To investigated the current-voltage $(I-V)$ relationship of ASIC-1a currents, MNTB neurons were successively patch clamped at different membrane potentials, from $-70 \mathrm{mV}$ to +60 $\mathrm{mV}$, every 2 min to allow full recovery of $\mathrm{I}_{\mathrm{ASIC}}$ (representative traces in Fig. $3 a$ ). The $I-V$ curve (Fig. $3 b ; n=6$ ) presents the peak amplitudes of $\mathrm{I}_{\mathrm{ASIC}} \mathrm{s}$ induced by a $3 \mathrm{~s}$ duration decrease in $\mathrm{pH}$ $k$ was $10.8 \pm 0.7 \mathrm{~s}(n=6)$.

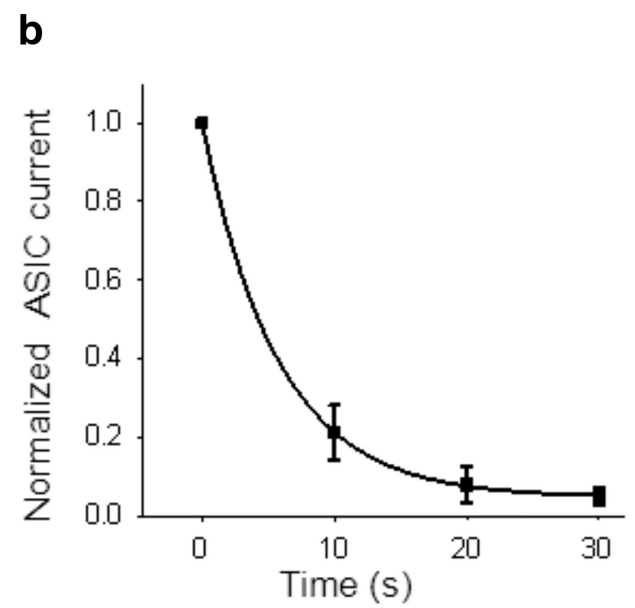

d

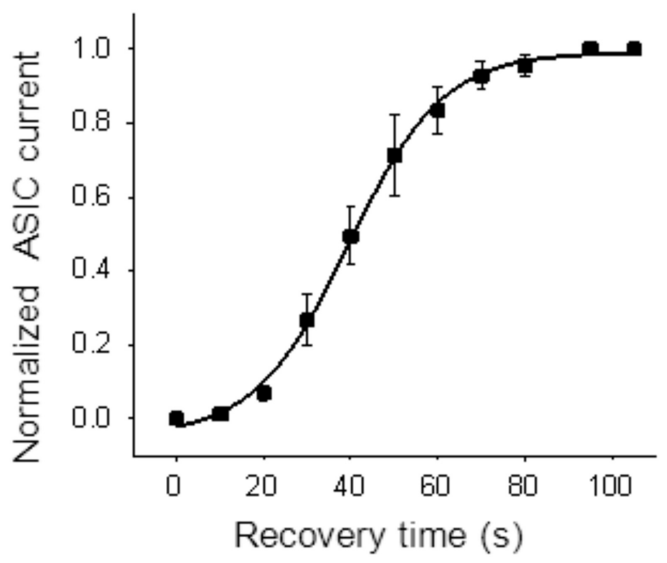

Figure 2. Desensitization of ASIC-1as. a, Representative ASIC currents activated by successive 3-s-long acidic puffs of a pH 6.0

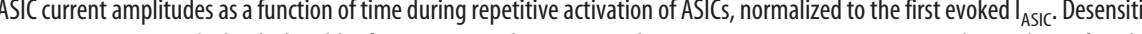

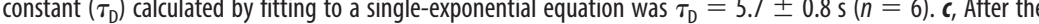
at $\mathrm{pH}$ 6.0. Recovery was quantified as the ratio between the peak current amplitude in response to the test $\mathrm{pH} 6.0 \mathrm{puff}$ and the tization, fitted by a sigmoid function: $/=1 /\left[1+\exp \left(\left(t-\tau_{\mathrm{R}}\right) / k\right)\right]$. The time for half-recovery $\left(\tau_{\mathrm{R}}\right)$ was $39.5 \pm 0.7 \mathrm{~s}$, and the slope

values from 7.3 to 6.5 at different membrane potentials. $\mathrm{I}_{\mathrm{ASIC}} \mathrm{S}$ had a reversal potential close to $+30 \pm 5 \mathrm{mV}(n=6)$, suggesting that ASIC-1as in MNTB neurons were mainly permeable to $\mathrm{Na}^{+}$ ions, together with a small but significant permeability to $\mathrm{Ca}^{2+}$ (see below).

\section{ASIC-1a activation in MNTB neurons increased intracellular $\mathrm{Ca}^{2+}$}

It has been reported that homomeric ASIC-1as are permeable to $\mathrm{Ca}^{2+}$ (Xiong et al., 2004, 2006; Yermolaieva et al., 2004). To investigate whether $\mathrm{Ca}^{2+}$ might enter MNTB neurons during ASIC-1a activation, we evoked $\mathrm{I}_{\mathrm{ASIC}} \mathrm{S}$ by $\mathrm{H}^{+}$iontophoresis (see Materials and Methods). To estimate transient changes in $\left[\mathrm{Ca}^{2+}\right]$ produced by the opening of ASIC-1as, the high-affinity $\mathrm{Ca}^{2+}$ indicator Fluo 8 was loaded into MNTB neurons. Upon binding to calcium, this dye exhibits an increase in fluorescence emission intensity. Calcium-mediated fluorescence images were taken before and after $\mathrm{H}^{+}$ejection from the pipette with a time interval of 

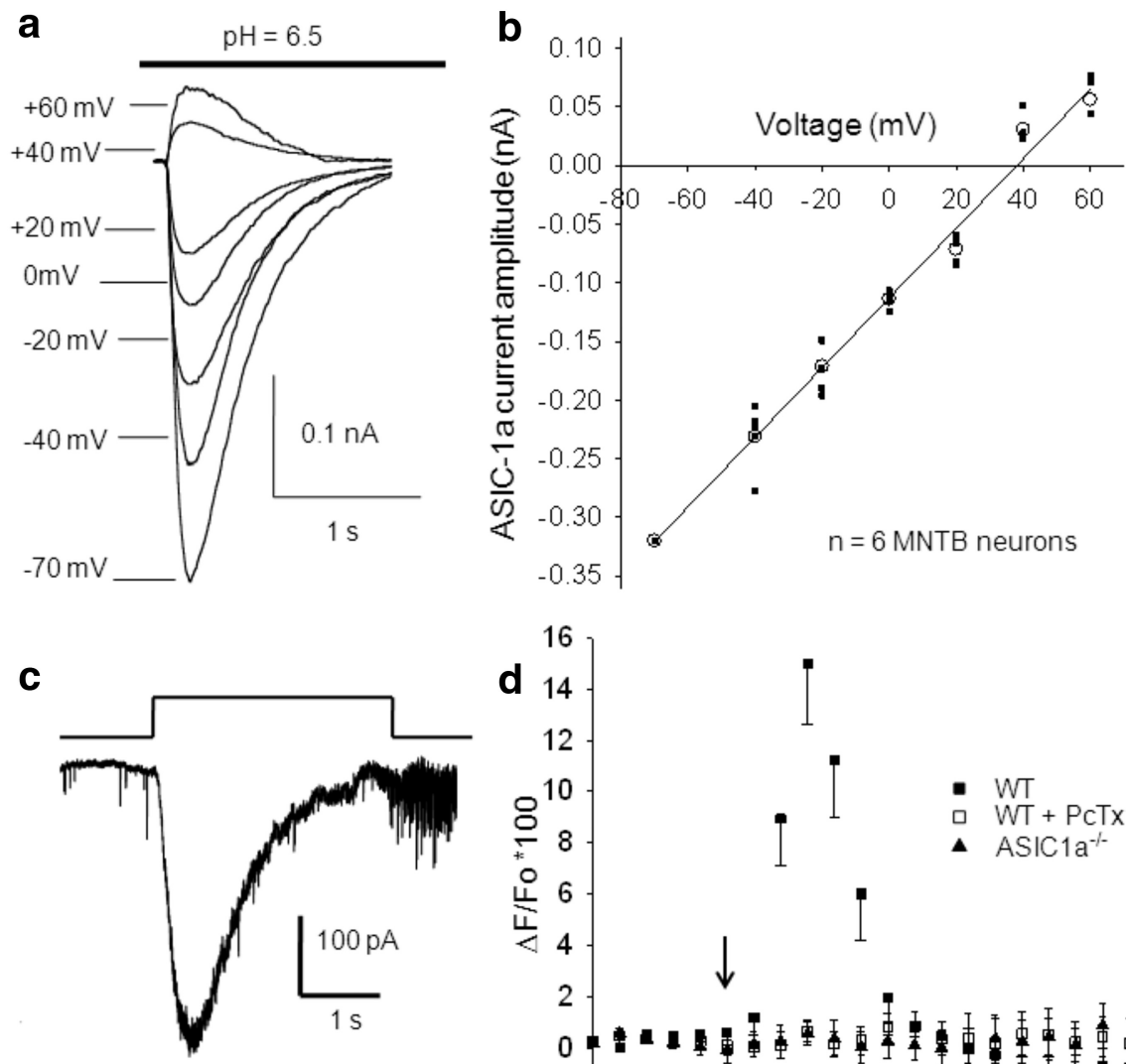

activated by presynaptic stimulation. To investigate the possible activation of ASICs by protons released presynaptically, we measured evoked EPSCs in the calyx MNTB neurons while electrically stimulating the presynaptic axons (see Materials and Methods). After pharmacologically blocking AMPA, NMDA, GABA and glycine receptors with 6-cyano-7-nitroquinoxaline-2,3-dione (CNQX; $40 \mu \mathrm{M}),(2 \mathrm{R})$-amino-5-phosphonovaleric acid (D-APV, 50 $\mu \mathrm{M})$, bicuculline $(20 \mu \mathrm{M})$, and strychnine (2 $\mu \mathrm{M})$, respectively, we could detect amiloride and PcTxl-sensitive postsynaptic currents (Fig. 4aI, aII). These currents detected in the postsynaptic neurons occurred in the same time frame as the AMPA-mediated EPSCs. Their amplitudes ( $46 \pm 3 \mathrm{pA}$ ) were remarkably smaller compared with glutamatergic EPSCs amplitudes and also compared with ASIC-1a currents evoked by exogenous $\mathrm{H}^{+}$. They have longer half-widths and decay times compared with glutamatergic EPSCs, as shown in Figure $4 b$ (Student's $t$ test, $p<$ $0.001 ; n=27$ MNTB neurons). Traces of these currents at different membrane potentials, as illustrated in Figure $4 c$, show that they have a reversal potential at positive voltages, as observed with prolonged extracellular acidification. These currents were absent in the ASICla ${ }^{-/-}$mice, confirming that they are mediated by ASIC-1a (Fig. $4 a I I I)$. Furthermore, increasing the $\mathrm{pH}$ buffering capacity using a $10 \mathrm{~mm}$ HEPES/ MES-based extracellular solution ( $\mathrm{pH}$ 7.3) in the ASIC-1a-dependent currents in MNTB neurons from WT mice was inhibited (Fig. $4 d ; n=6$ ). They were also abolished when ASIC-1as were desensitized using a $1 \mathrm{~mm}$ HEPES/MES-based extracellular solution at $\mathrm{pH} 6.0$ (Fig. $4 e ; n=3$ ). These results support the idea that synaptic vesicle content released on the synaptic cleft

Figure 3. Voltage dependence of ASIC currents and ASIC permeability to $\mathrm{Ca}^{2+}$. $\boldsymbol{a}$, Representative traces showing $\mathrm{I}_{\mathrm{ASI}} \mathrm{S}$ activated by a 3-s-long pH drop from 7.3 to 6.5 while MNTB neurons were whole-cell patch clamped at different holding potentials. from 7.3 to $6.5(n=6)$. The detection of calcium transients evoked during the activation of ASIC-1as by $\mathrm{H}^{+}$injection. $\mathbf{c}$, Representative traces of ASIC currents evoked by $\mathrm{H}^{+}$iontophoresis in WT mice. The bar indicates the positive current pulse $(2 \mathrm{nA}, 3$ s-duration) applied to a micropipette filled with $\mathrm{HCl} 0.1 \mathrm{~m}$ through a monopolar filament. $\boldsymbol{d}$, Changes in calcium-sensitive indicator $\Delta F / F_{0}$ as a function of time. The arrow indicates the time of iontophoretic injection of $\mathrm{H}^{+}$. In MNTB neurons from WT mice, the $\mathrm{Ca}^{2+}$-dependent fluorescence rises up to $15 \pm 3 \%$ (filled squares, $n=9$ ), indicating that $\mathrm{Ca}^{2+}$ enters into the MNTB neuron through ASIC-1as when these are activated by $\mathrm{H}^{+}$. This increment in $\left[\mathrm{Ca}^{2+}\right]$ is abolished when $\mathrm{PCTx} 1$ is applied to the bath solution (open squares; $n=8$ ) and was not observed in MNTB neurons from ASIC1a ${ }^{-/-}$mice (filled triangles; $n=4$ ).

$750 \mathrm{~ms}$. To generate curves of dye fluorescence intensity versus time, we used data from the background-corrected, normalized fluorescence images, as described in Materials and Methods. Figure $3 c$ shows an example of $\mathrm{I}_{\mathrm{ASIC}} \mathrm{s}$ evoked by a 3-s-duration iontophoretic current. $\mathrm{I}_{\mathrm{ASIC}} \mathrm{s}$ have mean peak amplitudes of $0.48 \pm 0.03 \mathrm{nA}$, mean half-widths of $0.74 \pm 0.05 \mathrm{~s}$, rise times of $0.31 \pm 0.04 \mathrm{~s}$, and decay times of $1.4 \pm 0.1 \mathrm{~s}(n=9)$. Figure $3 d$ (filled squares, $n=9$ ) depicts the average ratio $\Delta F / F_{0}$ as a function of time, showing a $\mathrm{Ca}^{2+}$-dependent increase in fluorescence (maximum, $15 \pm 3 \% ; n=9$ ) after ASIC-1a channel activation in MNTB neurons from WT mice. This increment in $\left[\mathrm{Ca}^{2+}\right]$ was inhibited by PcTx1 (Fig. $3 d$, open squares; $n=8 \mathrm{MNTB}$ neurons from WT mice) and was not observed in MNTB neurons from $\mathrm{ASICla}^{-/-}$mice (Fig. $3 d$, filled triangles; $n=4$ neurons).

\section{Protons released during presynaptic stimulation contribute to postsynaptic currents}

Studies in the lateral amygdala (Du et al., 2014) and nucleus accumbens core (Kreple et al., 2014), where both ASIC-1a and AISC-1a/2a are expressed, have shown a small contribution to EPSCs by ASICs upon stimulation of the calyx of Held presynaptic terminal includes glutamate and protons that activate postsynaptic ASICs.

\section{Are the ASIC-dependent signals relevant to synaptic transmission?}

To investigate the physiological relevance of ASICs, we performed current-clamp recordings to determine whether synaptic released $\mathrm{H}^{+}$were sufficient to trigger APs. We first recorded ASIC-1amediated EPSCs, visualized by blocking postsynaptic receptors with 2,3-dihydroxy-6-nitro-7-sulfonyl-benzo[f] quinoxaline (NBQX; 10 $\mu \mathrm{M})$, a higher-affinity AMPA receptor antagonist, plus D-APV (50 $\mu \mathrm{M})$, bicuculline $(20 \mu \mathrm{M})$, and strychnine $(2 \mu \mathrm{M})$, evoked by $100 \mathrm{~Hz}$ stimulation of presynaptic axons (Fig. $4 f$, top, black trace) and then switched to current-clamp mode. The resting potential of the neurons considered in the analysis varied between -60 and $-65 \mathrm{mV}$, with no current injection applied. In those conditions, we observed that ASIC-1a EPSCs were able to evoke APs whose amplitudes and kinetics did not differ from those evoked by glutamatergic currents (Fig. 4f, bottom, black trace). PcTx1 inhibited both ASIC-1amediated currents and evoked APs. However, ASIC-1a-mediated 
a

I)

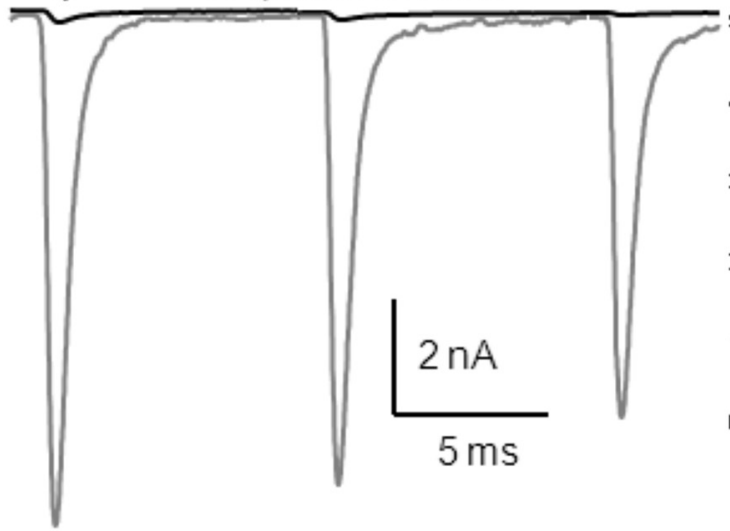

II) Amiloride

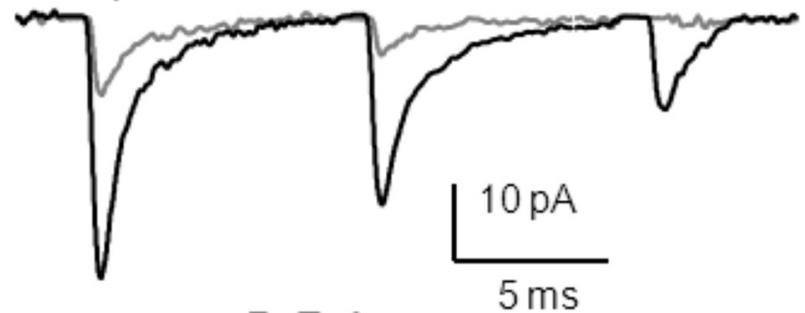

PcTx1

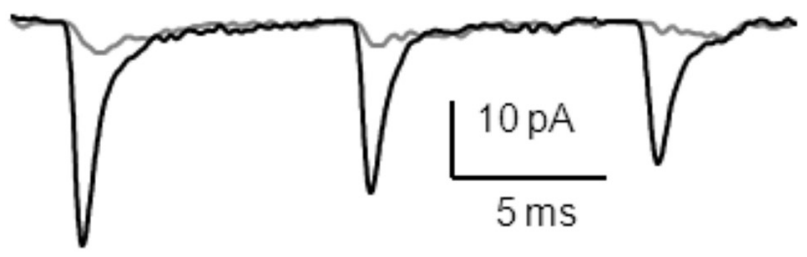

III)

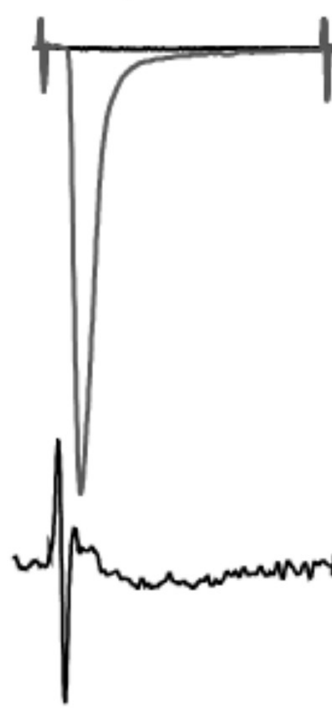

$2 \mathrm{nA}$

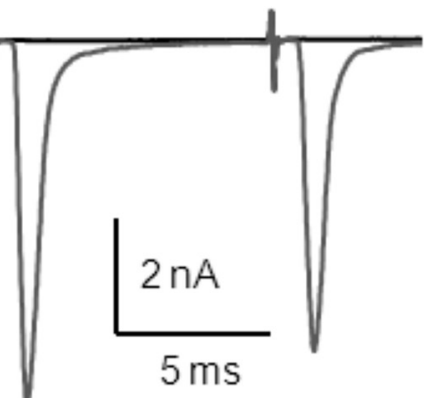

$5 \mathrm{~ms}$<smiles>C=CC</smiles>

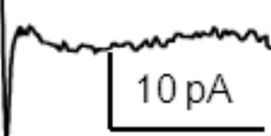

b

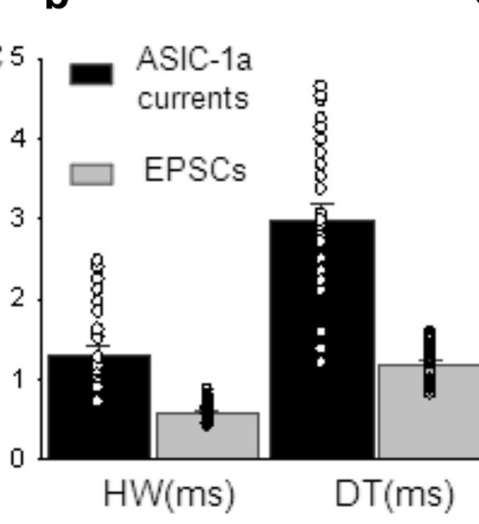

C

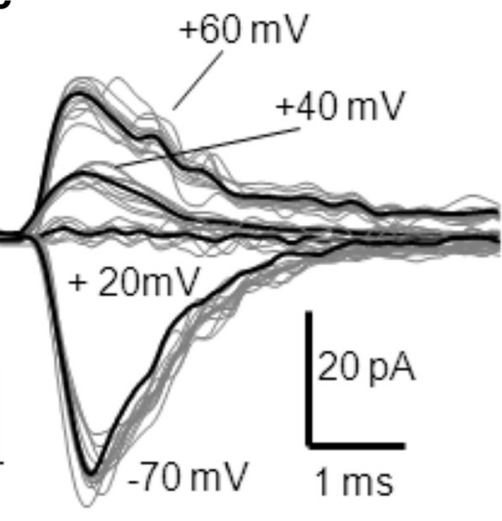

d Hepes/MES $10 \mathrm{mM}, \mathrm{pH}=7.3$

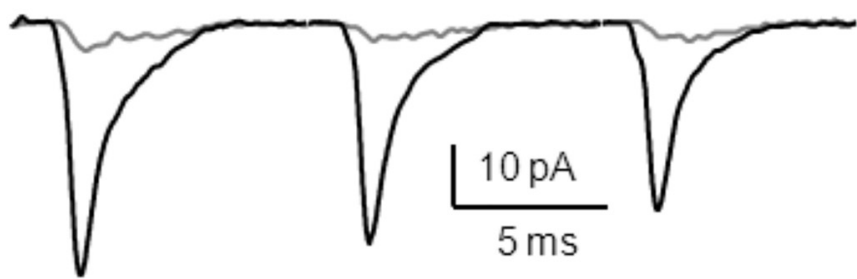

e Hepes/MES $1 \mathrm{mM}, \mathrm{pH}=6.0$
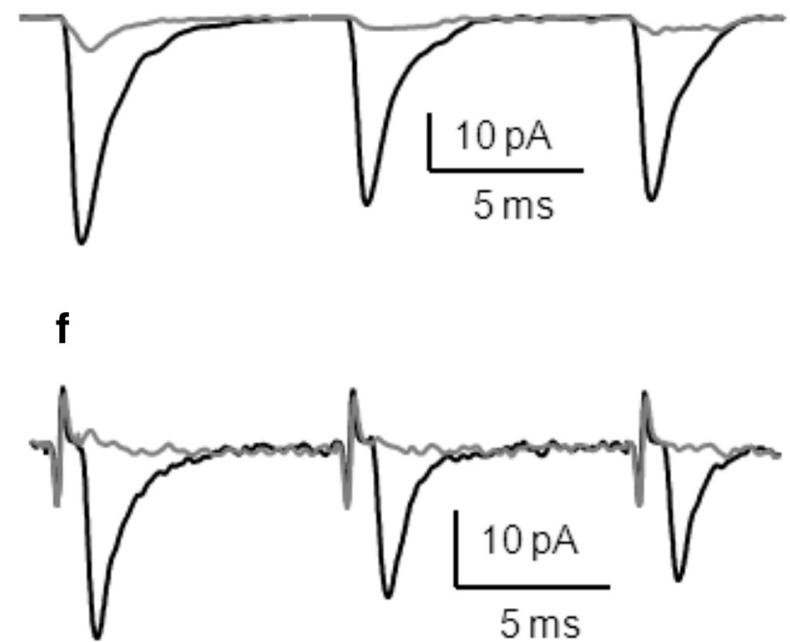

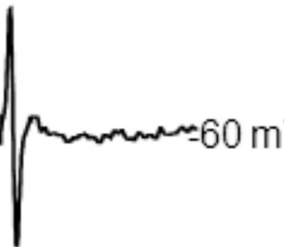

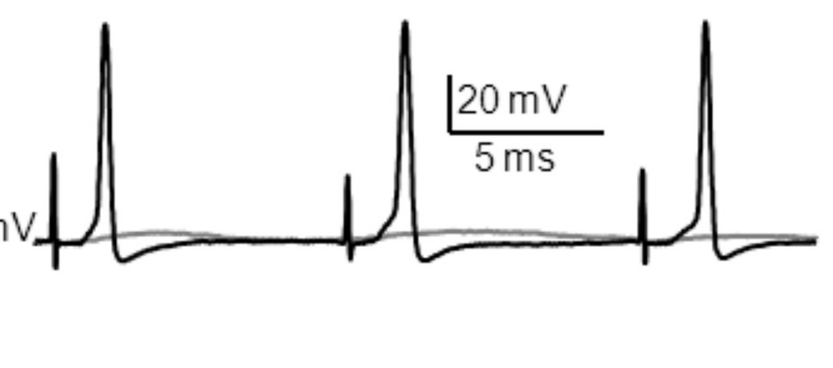

Figure 4. Blockage of glutamatergic EPSCs reveals that protons released from presynaptic vesicles elicit postsynaptic ASIC-mediated currents and action potentials in MNTB neurons from WT mice. al, Representative traces of EPSCs before (gray) and after (black) blocking AMPA, NMDA, GABA, and glycine receptors with CNQX (40 $\mu \mathrm{M}), \mathrm{D}-\mathrm{APV}(50 \mu \mathrm{M})$, bicuculline (20 $\mu \mathrm{M})$, and strychnine $(2 \mu \mathrm{M})$ in an MNTB neuron from a WT mouse [postnatal day 15 (P15)]. all, Higher magnification of the ASIC-1a-mediated currents insensitive to CNQX, APV, bicuculline, and strychnine (black). Mean amplitudes were $46 \pm 3 \mathrm{pA}(n=27)$. These ASIC-1a-mediated currents were highly reduced by amiloride (top, gray trace; $n=15)$ and were inhibited by PcTx1 (bottom, gray trace; $n=4)$. allI, Top, Representative traces of EPSCs before (gray) and after (black) blocking AMPA, NMDA, GABA, and glycine receptors with CNQX (40 $\mu \mathrm{M})$, D-APV (50 $\mu \mathrm{M})$, bicuculline (20 $\mu \mathrm{M})$, and strychnine $(2 \mu \mathrm{M})$ in an MNTB neuron from ASIC1a ${ }^{-1-}$ mouse (P16). Bottom, Higher-magnification image showing the absence of any current after postsynaptic receptor (Figure legend continues.) 
currents seem not to be very relevant in triggering postsynaptic action potential in physiological conditions since neither the fidelity of glutamatergic EPSCs nor the pattern and reliance of AP generation evoked by $100 \mathrm{~Hz}$ stimulation of presynaptic axons are affected in $\mathrm{ASICla}^{-1-}$ mice compared with WT mice when AMPA receptors are functional. Moreover, in a series of experiments where MNTB postsynaptic action potentials in WT mice were recorded extracellularly by a pipette filled with extracellular solution and in a loose patch-clamp configuration, the input/output relation at 150 and 300 $\mathrm{Hz}$ stimulation ( $500 \mathrm{~ms}$ ) was not altered by applying PcTx1 or increasing the buffer capacity with a $10 \mathrm{mM}$ HEPES-based solution. These results indicate that in normal physiological conditions, the activation of ASIC-1 as are contributing neither to AP patterns nor to the fidelity of the synaptic transmission.

During HFS, presynaptic released protons leads to an increase in intracellular $\mathrm{Ca}^{2+}$ in MNTB neurons through the activation of ASIC-1as

The observed ASIC-1a-mediated current contribution to the EPSC elicited by presynaptic nerve terminal stimulation makes it plausible that postsynaptic ASIC-1a channel activation in MNTB could permeate $\mathrm{Ca}^{2+}$ in generating a growing signal that might became detectable during the stimulation period.

To test this hypothesis, we stimulated presynaptic terminals at $150 \mathrm{~Hz}$ during $0.4 \mathrm{~s}$ and recorded glutamatergic EPSCs while simultaneously measuring the fluorescence emitted by the high-affinity $\mathrm{Ca}^{2+}$ indicator Fluo 8 loaded into MNTB neurons. Fluorescent images were taken every $140 \mathrm{~ms}$ (the first six images before stimulation as baseline) in normal bicarbonate-based aCSF containing NMDA, GABA, and glycine receptors antagonists (D-APV, $50 \mu \mathrm{M}$; bicuculline, $20 \mu \mathrm{M}$; strychnine, $2 \mu \mathrm{M}$ ). Only neurons with negligible leak current (and so stable resting potential) were considered in the analysis. During HFS, EPSCs underwent STD, as will be detailed in the next section, while an increase in fluorescence was observed in MNTB neurons from WT mice, mainly due to $\mathrm{Ca}^{2+}$ influx through AMPA receptors. Figure $5 a$ (left, filled squares; control, $n=9$ ) shows an average $\Delta F / F_{0}$ versus time curve, with a peak $\Delta F / F_{0}$ of $28 \pm 5 \%$. After AMPA/kainate glutamate receptor inhibition with CNQX $(40 \mu \mathrm{M})$, a small increment in fluorescence remained during $150 \mathrm{~Hz}$ stimulation (Fig. $5 a$, left, open squares; CNQX, peak $\Delta F / F_{0}=3.8 \pm$ $0.9 \%$ ). Psalmotoxin, the specific ASIC-1a blocker, inhibited this residual fluorescence increment (Fig. 5a, left, circles, +PcTx1), suggesting that the observed rise in intracellular $\mathrm{Ca}^{2+}$ was due to the activation of ASIC-1as in MNTB neurons during high-frequency synaptic activity. Applying blockers in reverse order, the maximum

\section{$\leftarrow$}

(Figure legend continued.) inhibition. $\boldsymbol{b}$, Mean half-width and decay time of amiloride and PCTx1-sensitive ASIC-1a-mediated currents compared with glutamatergic EPSCS (HW: $1.31 \pm$ $0.1 \mathrm{~ms}$ vs $0.59 \pm 0.03 \mathrm{~ms} ; \mathrm{DT}: 3.0 \pm 0.2 \mathrm{~ms}$ vs $1.18 \pm 0.05 \mathrm{~ms} ; n=27 ;$ Student's $t$ test, $p<$ 0.001). c, Sample traces of ASIC-1a currents at different membrane potentials in WT mouse (P14). d, Increasing pH buffering using a $10 \mathrm{~mm}$ HEPES-based extracellular solution, $\mathrm{pH} 7.3$, the ASIC-1a-mediated currents in MNTB neurons from WT mice were highly reduced (traces from a P15 mouse). e, ASIC-1a-mediated currents were highly diminished when the HEPES-based extracellular solution was maintained at $\mathrm{pH} 6.0$ due to the desensitization of ASICS (traces from a P17 mouse). $\boldsymbol{f}$, ASIC-1a-mediated currents (top, black trace) evoked by $100 \mathrm{~Hz}$ stimulation of presynaptic axons after the blockage of postsynaptic receptors with NBQX (a higher-affinity AMPA receptor antagonist, $10 \mu \mathrm{M}$ ) plus D-APV $(50 \mu \mathrm{M})$, bicuculline (20 $\mu \mathrm{M})$, and strychnine (2 $\mu \mathrm{m}$ ) in a P15 WT mouse. Mean amplitudes were $38 \pm 8 \mathrm{pA}$ (HW, $1.1 \pm 0.2 \mathrm{~ms}$; DT, $2.7 \pm 0.3$ $\mathrm{ms} ; n=7$ ). These currents were able to evoke APs (measured in current-clamp configuration at the resting potential of the MNTB neurons) whose amplitudes and kinetics did not differ from those evoked by glutamatergic currents (bottom, black trace; current-clamp recording). PcTx1 inhibited both ASIC-1a-mediated currents and evoked APs (gray traces). increase in fluorescence of $29 \pm 2 \%$ recorded in control conditions during $150 \mathrm{~Hz}$ stimulation (Fig. $5 a$, right, filled squares; control, $n=$ 10) was reduced to $24 \pm 3 \%$ after inhibiting ASIC-1as with PcTx1 (Fig. $5 a$, right, circles, + PcTx1). The addition of CNQX abolished any $\mathrm{Ca}^{2+}$ influx, as observed by the absence of fluorescence increase (Fig. $5 a$, right, open squares, $+\mathrm{CNQX}$ ). Therefore, inhibiting glutamate AMPA/kainate receptors reveals that these receptors contribute to $\sim 86 \pm 4 \%$ of the whole $\mathrm{Ca}^{2+}$ influx, while blocking ASIC- 1 as indicates that nearly $17 \pm 3 \%$ of the full amount of $\mathrm{Ca}^{2+}$ influx is mediated by these channels during high-frequency synaptic activity.

To further corroborate these data, we studied the reliance of ASIC-dependent intracellular $\mathrm{Ca}^{2+}$ increment with the $\mathrm{pH}$ buffer capability. If the intracellular $\mathrm{Ca}^{2+}$ increase was due to the opening of ASIC-1as during acidification, then a change in the $\mathrm{pH}$ buffering capacity of the aCSF would affect the increase in fluorescence of the Fluo $8 \mathrm{Ca}^{2+}$ indicator. In effect, using a low pH buffer capacity (HEPES 1 mM/MES) aCSF (pH 7.3), we found results similar to those obtained in normal bicarbonate-based aCSF, concerning the maximum increase in fluorescence induced during HFS in MNTB neurons from WT mice, both in control conditions (peak $\Delta F / F_{0}=28 \pm 8 \%, n=9$ MNTB neurons; Fig. 5b, filled squares, HEPES $1.0 \mathrm{~mm} / \mathrm{MES}$ ) and after AMPA and NMDA glutamate receptor inhibition with CNQX and D-APV (peak $\Delta F / F_{0}=3.2 \pm 0.8 \%, n=9$, Fig. $5 b$, open squares, HEPES $1.0 \mathrm{~mm} / \mathrm{MES}, \mathrm{CNQX}+\mathrm{APV})$. When slices were subsequently perfused with a high $\mathrm{pH}$ buffer capacity (10 mM HEPES/MES) aCSF ( $\mathrm{pH} 7.3$ ), with the addition of CNQX and D-APV, the remaining fluorescence was occluded (Fig. 5b, circles, HEPES 10 $\mathrm{mM} / \mathrm{MES}, \mathrm{CNQX}+\mathrm{APV})$.

The same experiments performed with ASIC- $1 \mathrm{a}^{-1-}$ mice using bicarbonate-based aCSF, showed an increment in intracellular $\mathrm{Ca}^{2+}$ during $150 \mathrm{~Hz}$ frequency stimulation that was not significantly different from those performed with WT mice (Fig. $5 c$, filled triangles; control, $n=8$ MNTB neurons), with a peak $\Delta F / F_{0}=26 \pm 5 \%\left(p>0.05\right.$, Student's $t$ test, WT vs ASIC-1a ${ }^{-/-}$ mice). After blocking glutamate receptors with $40 \mu \mathrm{M}$ CNQX and $50 \mu \mathrm{M}$ D-APV, no significant changes in fluorescence were observed during or after $150 \mathrm{~Hz}$ stimulation (Fig. $5 c$, open triangles, CNQX plus APV; $n=8 \mathrm{MNTB}$ neurons). These results show that a calcium-mediated postsynaptic signal is directly triggered by presynaptically evoked release of protons.

\section{ASICs modulate synaptic plasticity at the calyx of Held-MNTB synapse}

Is transmitter release affected by ASIC-1as? The activation of postsynaptic ASIC-1as as a result of HFS of the presynpatic calyx suggests that an acidification of the synaptic cleft is transiently induced and may modulate transmitter release. To investigate this subject, we recorded AP-evoked EPSCs from MNTB neurons in whole-cell voltage clamp at a resting potential of $-70 \mathrm{mV}$ in normal bicarbonatebased aCSF. There were no significant differences in peak amplitudes or time constants of EPSCs between WT and ASIC1a ${ }^{-/-}$ mice [WT mice: peak amplitude $=8.6 \pm 0.4 \mathrm{nA}, n=42 ; \mathrm{ASICla}^{-\prime-}$ mice: peak amplitude, $8.9 \pm 0.5 \mathrm{nA}, n=21$ (Student's $t$ test, $p=0.19)$; WT mice: decay time constant $=1.1 \pm 0.2 \mathrm{~ms}$; $\mathrm{ASICla}^{-1-}$ mice: decay time constant $=1.2 \pm 0.3 \mathrm{~ms}$ (Student's $t$ test, $p=0.33$ ); WT mice: half-width $=0.61 \pm 0.04$; ASIC1a $^{-1-}$ mice: half-width $=0.69 \pm 0.05 \mathrm{~ms}$ (Student's $t$ test, $p=0.28$ ); WT mice: rise time $=0.19 \pm 0.01 ; \mathrm{ASICla}^{-1-}$ mice: rise time $=0.21 \pm$ $0.01 \mathrm{~ms}$ (Student's $t$ test, $p=0.44$ )].

To study synaptic plasticity, we evoked synaptic response at repetitive HFS $(300 \mathrm{~Hz}, 20$ stimuli). HFS at the calyx of HeldMNTB synapse caused STD; EPSC amplitudes decreased during 
the train of stimuli until they reached a steady state (Fig. 6a). Plots of mean EPSC amplitudes as a function of time during $300 \mathrm{~Hz}$ stimulation, with the corresponding parameters of the exponential decay fitting are shown in Figure 6b. EPSCs exhibited stronger STD and a faster decay time course $(\tau)$ in ASIC1a ${ }^{-1-}$ mice than in WT mice ( $p<0.05$, one-way ANOVA).

PcTx1 has no effect on single APevoked EPSCs in WT mice, but it does have an effect on STD, replicating the results observed in ASIC-1a ${ }^{-1-}$ mice. Figure $6 c$ shows the time course dependence of EPSC amplitudes during $300 \mathrm{~Hz}$ stimulation before and after the application of PcTx1 (10 nM), fitted by the corresponding single exponential decay function $(n=9)$. The inset represents the decay time constants $(\tau)$ in the absence and presence of PcTxl in the aCSF for each neuron, together with the mean $\tau$ values. There is a significant increase in STD when ASIC-las are blocked by PcTx1 ( $p=4 \times 10^{-5}$; paired Student's $t$ test).

To further corroborate that ASIC-1as are activating during HFS and modulating STD, the same experiments were performed in two solutions with different $\mathrm{pH}$ buffer capacities. STD measured in slices from WT mice in a low $\mathrm{H}^{+}$buffer capacity (1 mM HEPES/MES) aCSF was attenuated with respect to that measured in a high $\mathrm{H}^{+}$buffer capacity (10 mM HEPES/ MES) aCSF, as shown in Figure $6 d$. The inset shows the decay time constants $(\tau)$ of STD in $n=8$ MNTB neurons, measured sequentially in the 1 and 10 mM HEPESbased aCSF, jointly with the corresponding mean $\tau$ values. There is a significant increase in STD when acidification is inhibited by the high $\mathrm{H}^{+}$buffer capacity of the $10 \mathrm{~mm}$ HEPES solution $(p<0.001$, paired Student's $t$ test).

\section{Discussion}

The calyx of Held-MNTB synapse provides a model system to analyze basic mechanisms of synaptic transmission. We have investigated the role of protons on synaptic transmission, acting through the activation of ASICs. We have demonstrated that MNTB neurons from mice respond to a drop in $\mathrm{pH}$ with an amiloride-sensitive transient inward current whose reversal potential was close to that of currents mediated by $\mathrm{Na}^{+} / \mathrm{Ca}^{2+}$, indicating that functional ASICs of the $\mathrm{ENaC} /$ degenerin family are expressed in these neurons. These ASIC-mediated currents were abolished by PcTx1, a toxin that specifically blocks homomeric ASIC-1a by increasing the $\mathrm{pH}$ sensitivity of steady-state desensitization and causing ASIC-las to desensitize at pH 7.4 (Escoubas et al., 2000; Chen et al., 2006). The inhibition of $\mathrm{I}_{\mathrm{ASIC}} \mathrm{s}$ by PcTx1 in WT mice and the absence of currents in $\mathrm{ASICla}^{-1-}$ mice identified homomeric ASIC-1as as the main isoform of ASICs in MNTB neurons. Furthermore, ASIC activation induced membrane depolarization
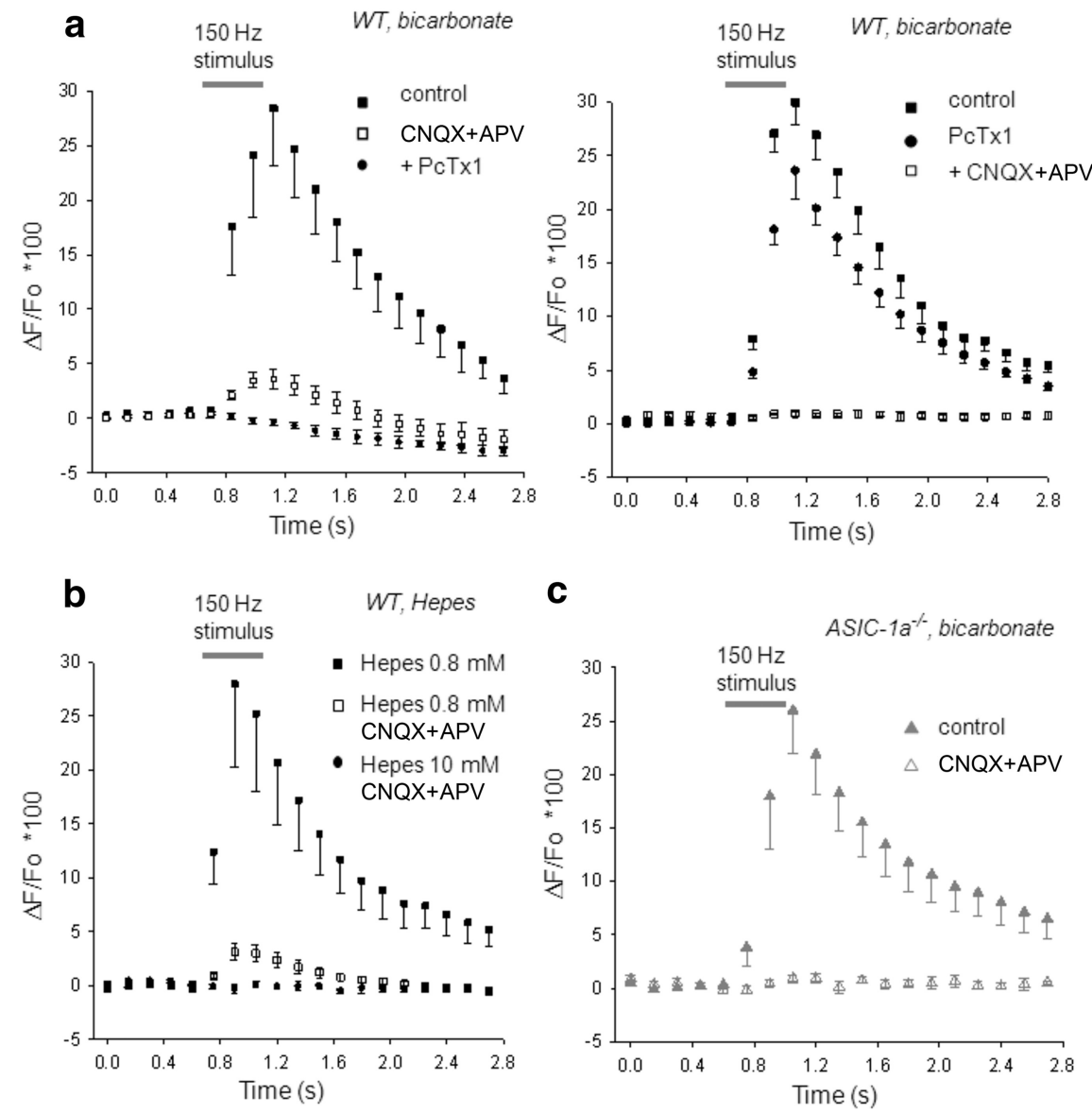

Figure 5. ASIC-1a-dependent increase of intracellular $\mathrm{Ca}^{2+}$ in MNTB neurons during HFS. $\boldsymbol{a}$, Time course of the Fluo 8 fluorescence emission ratio $\left(\Delta F / F_{0}\right)$ in postsynaptic MNTB neurons from WT mice $(n=9)$ during presynaptic $\mathrm{HFS}(150 \mathrm{~Hz}, 0.4 \mathrm{~s}$; indicated by gray bar) in normal bicarbonate-based aCSF. Images were taken every $140 \mathrm{~ms}$ (first six images before stimulation served as the After AMPA/kainite glutamate receptor inhibition with $40 \mu \mathrm{M}$ CNQX (open squares, (NQX), a small component of the fluorescence increment (peak, $3.8 \pm 0.9 \% ; n=9$ ) remained during $150 \mathrm{~Hz}$ stimulation. PcTx1 inhibited this residual fluorescence (circles, + increase in intracellular $\mathrm{Ca}^{2+}$ of $29 \pm 2 \%$ in control conditions ( $n=10$; filled squares, control) to $24 \pm 3 \%$ (circles, PcTx1), while the addition of CNQX abolished any increase in fluorescence during $150 \mathrm{~Hz}$ stimulation (open squares, CNQX). $\boldsymbol{b}$, Changing the pH HFS in a low-pH buffer capacity aCSF before (filled squares, HEPES $1 \mathrm{~mm}$; peak increase, $28 \pm 8 \% ; n=9$ ) and after the inhibition of glutamate AMPA and NMDA receptors (open squares, HEPES 1 mm plus CNQX + APV; peak increment, $3.2 \pm 0.8 \%, n=9$ ). This capacity aCSF inhibits acidification (circles, HEPES $10 \mathrm{~mm} ; n=9 ; p<0.05$, one-way repeated-measures ANOVA).c, Time course of $\Delta F / F_{0}$ in postsynaptic MNTB neurons from ASIC1a ${ }^{-/-}$mice during $\mathrm{HFS}(150 \mathrm{~Hz}, 0.4 \mathrm{~s})$ in normal bicarbonate-based aCSF (filled that observed in WT mice ( $p>0.05$, Student's $t$ test, WT vs ASIC-1a $\left.{ }^{-l-}\right)$. After glutamate AMPA and NMDA receptor inhibition, the increase in fluorescence is completely eliminated (open triangles, $C \mathrm{NQX}+\mathrm{APV} ; n=8$ ).

and triggered action potentials in WT MNTB neurons, an effect that has been reported in cortical, hippocampal, retinal ganglion, and spinal cord neurons (Baron et al., 2002, 2008; Chu et al., 2004, Lilley et al., 2004; Wu et al., 2004). In contrast, no presynaptic $\mathrm{I}_{\mathrm{ASIC}} \mathrm{S}$ were observed in the nerve terminal during local acidification.

ASIC-1a has a low but significant permeability to $\mathrm{Ca}^{2+}$ that has been suggested to be physiologically relevant (Xiong et al., 2004, 2006; Yermolaieva et al., 2004; Ziemann et al., 2008). We have confirmed that ASIC-1a activation induces an increase in calcium influx into the postsynaptic cell, as indicated by the increase in fluorescence of the high-affinity $\mathrm{Ca}^{2+}$ indicator Fluo 8 during iontophoretic extracellular application of $\mathrm{H}^{+}$ (Fig. 3d). 

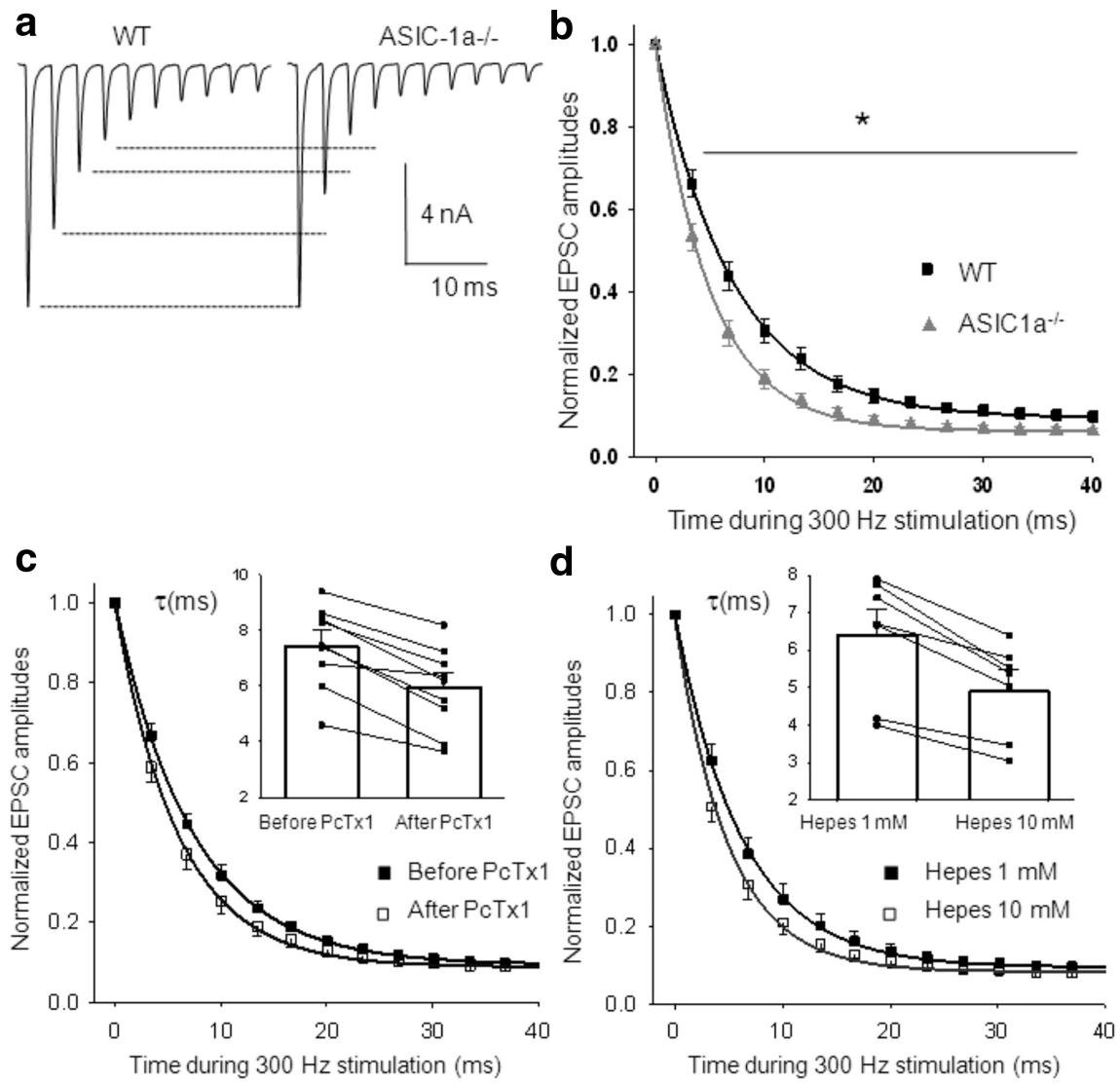

Figure 6. Enhanced STD at excitatory synaptic transmission in $\mathrm{ASIC}_{\mathrm{a}}{ }^{-1-}$ mice compared with WT mice. $\boldsymbol{a}$, Representative recording of AP-evoked EPSCs in WT and ASIC1a ${ }^{-1-}$ MNTB neurons during $300 \mathrm{~Hz}$ stimulation. $\boldsymbol{b}$, Time course of EPSC peak amplitudes (normalized to the first EPSC amplitude in the train) during $0.7 \mathrm{~s} \mathrm{stimulation} \mathrm{at} 300 \mathrm{~Hz}$, fitted to a single exponential decay function, with a mean decay time constant $\tau=7.0 \pm 0.5 \mathrm{~ms}$ in WT mice $(n=42)$ and $\tau=5.0 \pm 0.6 \mathrm{~ms} \mathrm{in} \mathrm{ASIC1a}^{-1-}$ mice ( $n=21 ; p=0.01$, Student's $t$ test). The EPSC amplitudes at the end of the stimuli reach a steady-state value of $9.3 \pm 0.2 \%$ and $6.2 \pm 0.2 \%$, respectively, of the first EPSC amplitude in the train, in WT and ASIC $1 \mathrm{a}^{-1-}$ mice ( $p=0.04$, Student's $t$ test). ${ }^{*} p<0.05$, one-way repeated-measures ANOVA. c, Effect of PcTx1 on STD in WT mice. Normalized EPSC amplitudes as a function of time recorded in WT MNTB neurons during $300 \mathrm{~Hz}$ stimulation in bicarbonate-based aCSF at pH 7.3 before (filled squares) and during (open squares) the application of PcTX1 in the external solution. Data fitted to a single exponential decay function show an enhanced STD when ASIC-1as are blocked (mean decay time constants: before application of PCTx1, $\tau=7.3 \pm 0.6 \mathrm{~ms}$; after application of $\mathrm{PcTx} 1, \tau=5.96 \pm 0.53 \mathrm{~ms} ; n=9$ ). Inset, Individual and mean $\tau$ values, $p=4 \times 10^{-5}$, paired student's $s$ test). Steady-state values of EPSC amplitudes at the end of the stimuli are also statistically different (before application of PCTx1, $9.4 \pm$ $0.7 \%$ of the first EPSC amplitude in the train; after application of PCTX1, $8.8 \pm 0.8 \%$ of the first EPSC amplitude in the train; $p=$ 0.002 , paired Student's $t$ test). $\boldsymbol{d}$, Effect of pH buffering on STD in WT mice. Time course of normalized EPSC amplitudes during 300 Hz stimulation recorded sequentially in a $1 \mathrm{~mm}$ (filled squares) and $10 \mathrm{~mm}$ (open squares) HEPES/MES-based aCSF $(n=8)$, fitted by single exponential decay functions. When acidification is inhibited by a high-pH buffer capacity solution, STD is increased (mean decay time constants: HEPES $1 \mathrm{mm:} \tau=6.4 \pm 0.7 \mathrm{~ms}$; HEPES $10 \mathrm{~mm}: \tau=4.9 \pm 0.6 \mathrm{~ms})$. Inset, Individual $\tau$ values and mean $(n=$ $8, p=6 \times 10^{-4}$, paired Student's $t$ test). Steady-state values of EPSC amplitudes at the end of the stimuli are $9.5 \pm 0.9 \%$ vs $8.3 \pm 0.9 \%$ of the first EPSC amplitude in the train, in HEPES $1 \mathrm{~mm}$ and HEPES $10 \mathrm{~mm}$, respectively $(p=0.005$, paired Student's $t$ test).

Since ASICs are activated by extracellular protons, it is reasonable that they are involved in biological processes where extracellular acidosis occurs. The $\mathrm{pH}$ inside synaptic vesicles is acidic ( $\mathrm{pH}<6.0$; Miesenböck et al., 1998), and protons are released from synaptic vesicles during synaptic transmission. These protons can lower the $\mathrm{pH}$ of the synaptic cleft (Krishtal et al., 1987; Trapp et al., 1996a,b) and affect $\mathrm{pH}$-sensitive ion channel activity. Actually, we have identified ASIC-1a-dependent currents in MNTB neurons from WT mice during synaptic transmission whose amplitudes are small relative to glutamatergic AMPAmediated EPSCs. These currents are blocked by amiloride and PcTx1 and are not observed in MNTB neurons from ASIC1a ${ }^{-1-}$ mice. They are also inhibited when a high $\mathrm{pH}$-buffering extracel- lular solution avoids acidification of the synaptic space or when ASICs are desensitized due to a sustained low $\mathrm{pH}$ of the extracellular solution (Fig. 4). Although small, these ASIC-1a-dependent signals could be relevant to synaptic transmission since they are able to generate APs in the absence of glutamatergic currents (Fig. $4 f)$. However, it should be considered that our experimental conditions included AMPA, NMDA, GABA, and glycine receptor antagonists that can artificially increase the input resistance of the MNTB cells and, thus, may help the small ASIC EPSCs to evoke the postsynaptic spikes.

We also observed an increase in intracellular $\mathrm{Ca}^{2+}$ in MNTB neurons that can be assigned to a calcium influx through ASIClas activated by protons released from synaptic vesicles during physiological HFS of presynaptic terminals (Fig. 5). The $\mathrm{Ca}^{2+}$ signal throughout ASICs located at the postsynapsis is small compared with the signal generated by the activation of AMPA receptors but may serve a specific purpose, like modulating transmitter release, due to their localization and/or association with other signaling molecules linked to a specific pathway (Zha, 2013). At the postsynaptic sites, ASIC-1 as have been linked to synaptic protein PICK1 (Hruska-Hageman et al., 2002; Jin et al., 2010). This interaction may be important for the localization and/or function of these channels in cell signaling. Given that, during synaptic transmission, the most likely source of protons is from presynaptic neurotransmitter-containing vesicles, detecting ASIC-dependent currents and $\mathrm{Ca}^{2+}$ influx reinforces the idea of protons acting as neurotransmitters in fast synapses. By contributing to neurotransmission, these results suggest that ASICs can modify membrane voltage and synaptic intracellular $\mathrm{Ca}^{2+}$, modulating synaptic strength and plasticity.

The relevance of ASICs on transmitter release at the calyx of Held-MNTB synapse was investigated by comparing glutamatergic EPSCs in neurons from WT and $\mathrm{ASICla}^{-1-}$ mice. EPSC amplitudes were not different between genotypes and were not affected by psalmotoxin. However, synaptic transmission during HFS, which induces maximal exocytosis of synaptic vesicle contents and extracellular reduction of $\mathrm{pH}$, reveals a modulation of synaptic plasticity by ASIC activation. The lack of ASIC-1as or their pharmacological inhibition during presynaptic HFS results in a faster and stronger STD with lower steady-state values of EPSC amplitudes at the end of the stimuli. In WT mice, PcTxl mimics the effect on STD that was observed on ASICla ${ }^{-1-}$ mice (Fig. 6c), and the same happened when STD was measured in a high-pH buffer capacity aCSF that avoided acidification and the subsequent ASIC activation (Fig. $6 d$ ). Therefore, presynaptically re- 
leased protons modulate presynaptic neurotransmitter release through the activation of the ASICs.

The quantal content of transmitter release during HFS is controlled by an intricate balance between $\mathrm{Ca}^{2+}$-dependent depletion and the replenishment of synaptic vesicles. Previous studies (Cho et al., 2008) using microisland cultures of hippocampal neurons demonstrated increased probability of glutamate release in neurons from ASIC-1-lacking mice. Our group has also shown that pharmacological and genetic disruption of ASIC-1a activity resulted in an enhancement of transmitter release at the neuromuscular junction (Urbano et al., 2014). At the calyx of Held during HFS, no difference was observed in the initial EPSC, but a stronger reduction in amplitude was observed in the following EPSCs when ASICs were not active, indicating that, through an undisclosed pathway, ASIC activation increases probability of release or the size of the synaptic vesicle ready releasable pool. Future experiments aimed to interfere with a possible retrograde signal will provide important clues on the ASIC-dependent synaptic transmission neuromodulation system.

A pH modulation of the EPSCs by protons acting on the postsynaptic glutamate receptors cannot be ruled out. NMDA receptors are strongly inhibited by protons (Traynelis and Cull-Candy, 1991) and at physiologically relevant $\mathrm{pH}$, protons inhibit glutamate AMPA-evoked currents and enhance the apparent rate and extent of AMPA receptor desensitization (Ihle and Patneau, 2000; Lei et al., 2001). Thus, during HFS, an increased rate of STD could result from an enhanced postsynaptic AMPA desensitization. However, in our hands, this mechanism does not seem to be physiologically relevant since changes in STD are observed in ASICla ${ }^{-1-}$ mice and are mimicked by PcTx1 in WT mice.

Since ASICs were not observed at the presynpatic terminals, we assume that during HFS ASICs located at the MNTB neurons or astrocytes may trigger a retrograde signal toward the presynaptic terminal. Astrocytes surrounding the calyx of Held-MNTB synapse are part of the synaptic structure and extend their fine processes between the fingers of the calyx of Held and the principal neuron contacting both presynaptic and postsynaptic membranes (Renden et al., 2005; Reyes-Haro et al., 2010). Although the existence of ASICs has been shown in cultured astrocytes from rat cortical tissues (Huang et al., 2010), at present there is no information regarding the expression of ASICs in the calyx of Held astrocytes. The presynaptic modulation could also result from the action of $\mathrm{pH}$ changes on other ion channels or receptors like $\mathrm{Ca}^{2+}$ channels. In photoreceptor synapses, neurotransmission lowers $\mathrm{pH}$ sufficiently to inhibit presynaptic $\mathrm{L}$-type $\mathrm{Ca}^{2+}$ channels, which mediate transmitter release (DeVries, 2001; Vessey et al., 2005). Also, proton-mediated blockage of $\mathrm{Ca}^{2+}$ channels during multivesicular release regulates short-term plasticity at auditory hair cell synapses (Cho and von Gersdorff, 2014). In contrast, $P / Q$-type channels, which mediate transmitter release at the developed calyx of Held, are poorly affected by $\mathrm{pH}$ changes (Shah et al., 2001; Cens et al., 2011). Furthermore, pH changes in the cleft are expected not to last long enough to modulate the calcium current generated by the next action potential during HFS.

What is the physiological role of proton-ASIC signaling in neurotransmission? Compared with AMPA-mediated glutamatergic currents, ASIC currents make a very small contribution to EPSCs induced by a single pulse. Proton signals may be particularly important during intense presynaptic stimulation where glutamatergic signals are subject to receptor desensitization. The combination of unusually fast deactivation with slow desensiti- zation enables ASICs to follow trains of brief stimuli at high frequencies, suggesting that they may sustain postsynaptic responses when other receptors desensitize (MacLean and Jayaraman, 2016). A hypothesis to be tested at the calyx of Held from young animals, where postsynaptic glutamate receptors are highly desensitized by HFS. Furthermore, the $\mathrm{Ca}^{2+}$ signal detected through ASIC-1as may serve a specific purpose due to the localization and or association with other signaling molecules. These effects could explain the involvement of protons and the requirement of ASICs for long-term potentiation induced by HFS (Wemmie et al., 2002).

In summary, our results support the concept that protons coreleased with glutamate act as neurotransmitters during acidification of the synaptic cleft. Electrophysiological recordings and $\mathrm{Ca}^{2+}$ imaging studies demonstrate that ASICs are the main postsynaptic proton receptors in the MNTB. The distribution and $\mathrm{pH}$ sensitivity of ASICs put them in a perfect position to sense $\mathrm{pH}$ reduction at a $\mathrm{pH}$ of $\sim 7$. Activation of ASICs modulates transmitter release and synaptic plasticity (short-term plasticity). Short-term plasticity is important in processing information in neural networks (e.g., producing a reliable response to repetitive activity), and, thus, changes in short-term plasticity may affect cognitive function, which is not surprising after taking into account that ASIC1 are required for normal behavioral responses to stresses such as amygdala-dependent fear-related learning and memory (Wemmie et al., 2002, 2003, 2006). The consequences of ASIC1 disruption are complex and influence both presynaptic and postsynaptic mechanisms.

\section{References}

Baron A, Deval E, Salinas M, Lingueglia E, Voilley N, Lazdunski M (2002) Protein kinase $\mathrm{C}$ stimulates the acid-sensing ion channel ASIC2a via the PDZ domain-containing protein PICK1. J Biol Chem 277:50463-50468. CrossRef Medline

Baron A, Voilley N, Lazdunski M, Lingueglia E (2008) Acid sensing ion channels in dorsal spinal cord neurons. J Neurosci 28:1498-1508. CrossRef Medline

Cens T, Rousset M, Charnet P (2011) Two sets of amino acids of the domain I of Cav2.3 $\mathrm{Ca}^{2+}$ channels contribute to their high sensitivity to extracellular protons. Pflugers Arch 462:303-314. CrossRef Medline

Chen CC, England S, Akopian AN, Wood JN (1998) A sensory neuronspecific, proton-gated ion channel. Proc Natl Acad Sci U S A 95:1024010245. CrossRef Medline

Chen X, Kalbacher H, Gründer S (2006) Interaction of acid-sensing ion channel (ASIC) 1 with the tarantula toxin psalmotoxin 1 is state dependent. J Gen Physiol 127:267-276. CrossRef Medline

Chesler M (2003) Regulation and modulation of $\mathrm{pH}$ in the brain. Physiol Rev 83:1183-1221. CrossRef Medline

Cho JH, Askwith CC (2008) Presynaptic release probability is increased in hippocampal neurons from ASIC1 knockout mice. J Neurophysiol 99: 426-441. CrossRef Medline

Cho S, von Gersdorff H (2014) Proton-mediated block of $\mathrm{Ca}^{2+}$ channels during multivesicular release regulates short-term plasticity at an auditory hair cell synapse. J Neurosci 34:15877-15887. CrossRef Medline

Chu XP, Xiong ZG (2012) Physiological and pathological functions of acidsensing ion channels in the central nervous system. Curr Drug Targets 13:263-271. CrossRef Medline

Chu XP, Wemmie JA, Wang WZ, Zhu XM, Saugstad JA, Price MP, Simon RP, Xiong ZG (2004) Subunit-dependent high-affinity zinc inhibition of acid-sensing ion channels. J Neurosci 24:8678-8689. CrossRef Medline

DeVries SH (2001) Exocytosed protons feedback to suppress the $\mathrm{Ca}^{2+}$ current in mammalian cone photoreceptors. Neuron 32:1107-1117. CrossRef Medline

Du J, Reznikov LR, Price MP, Zha XM, Lu Y, Moninger TO, Wemmie JA, Welsh MJ (2014) Protons and ASICs are a neurotransmitter/receptor pair that regulates synaptic plasticity in the lateral amygdala. Proc Natl Acad Sci U S A 111:8961-8966. CrossRef Medline

Escoubas P, De Weille JR, Lecoq A, Diochot S, Waldmann R, Champigny G, Moinier D, Ménez A, Lazdunski M (2000) Isolation of a tarantula toxin specific for a 
class of proton-gated $\mathrm{Na}^{+}$channels. J Biol Chem 275:25116-25121. CrossRef Medline

Friese MA, Craner MJ, Etzensperger R, Vergo S, Wemmie JA, Welsh MJ, Vincent A, Fugger L (2007) Acid-sensing ion channel-1 contributes to axonal degeneration in autoimmune inflammation of the central nervous system. Nat Med 13:1483-1489. CrossRef Medline

Gründer S, Pusch M (2015) Biophysical properties of acid-sensing ion channels (ASICs). Neuropharmacology 94:9-18. CrossRef Medline

Hnasko TS, Edwards RH (2012) Neurotransmitter corelease: mechanism and physiological role. Annu Rev Physiol 74:225-243. CrossRef Medline

Hruska-Hageman AM, Wemmie JA, Price MP, Welsh MJ (2002) Interaction of the synaptic protein PICK1 (protein interacting with C kinase 1) with the non-voltage gated sodium channels BNC1 (brain $\mathrm{Na}^{+}$channel 1) and ASIC (acid-sensing ion channel). Biochem J 361:443-450. CrossRef Medline

Huang C, Hu ZL, Wu WN, Yu DF, Xiong QJ, Song JR, Shu Q, Fu H, Wang F, Chen JG (2010) Existence and distinction of acid-evoked currents in rat astrocytes. Glia 58:1415-1424. CrossRef Medline

Huang Y, Jiang N, Li J, Ji YH, Xiong ZG, Zha XM (2015) Two aspects of ASIC function: synaptic plasticity and neuronal injury. Neuropharmacology 94:42-48. CrossRef Medline

Ihle EC, Patneau DK (2000) Modulation of a-amino-3-hydroxy-5-methyl4-isoxazolepropionic acid receptor desensitization by extracellular protons. Mol Pharmacol 58:1204-1212. CrossRef Medline

Jin W, Shen C, Jing L, Zha XM, Xia J (2010) PICK1 regulates the trafficking of ASICla and acidotoxicity in a BAR domain lipid binding-dependent manner. Mol Brain 3:39. CrossRef Medline

Kellenberger S, Schild L (2015) International Union of Basic and Clinical Pharmacology. XCI. Structure, function, and pharmacology of acidsensing ion channels and the epithelial $\mathrm{Na}^{+}$channel. Pharmacol Rev 67:1-35. CrossRef Medline

Kreple CJ, Lu Y, Taugher RJ, Schwager-Gutman AL, Du J, Stump M, Wang Y, Ghobbeh A, Fan R, Cosme CV, Sowers LP, Welsh MJ, Radley JJ, LaLumiere RT, Wemmie JA (2014) Acid-sensing ion channels contribute to synaptic transmission and inhibit cocaine-evoked plasticity. Nat Neurosci 17:1083-1091. CrossRef Medline

Krishtal O (2003) The ASICs: signaling molecules? Modulators? Trends Neurosci 26:477-483. CrossRef Medline

Krishtal OA, Osipchuk YV, Shelest TN, Smirnoff SV (1987) Rapid extracellular $\mathrm{pH}$ transients related to synaptic transmission in rat hippocampal slices. Brain Res 436:352-356. CrossRef Medline

Lei S, Orser BA, Thatcher GR, Reynolds JN, MacDonald JF (2001) Positive allosteric modulators of AMPA receptors reduce proton-induced receptor desensitization in rat hippocampal neurons. J Neurophysiol 85:20302038. Medline

Li T, Yang Y, Canessa CM (2012) Impact of recovery from desensitization on acid-sensing ion channel-1a (ASIC1a) current and response to high frequency stimulation. J Biol Chem 287:40680-40689. CrossRef Medline

Lilley S, LeTissier P, Robbins J (2004) The discovery and characterization of a proton-gated sodium current in rat retinal ganglion cells. J Neurosci 24:1013-1022. CrossRef Medline

Lingueglia E, de Weille JR, Bassilana F, Heurteaux C, Sakai H, Waldmann R, Lazdunski M (1997) A modulatory subunit of acid sensing ion channels in brain and dorsal root ganglion cells. J Biol Chem 272:29778-29783. CrossRef Medline

MacLean DM, Jayaraman V (2016) Acid-sensing ion channels are tuned to follow high-frequency stimuli. J Physiol 594:2629-2645. CrossRef Medline

Miesenböck G, De Angelis DA, Rothman JE (1998) Visualizing secretion and synaptic transmission with $\mathrm{pH}$-sensitive green fluorescent proteins. Nature 394:192-195. CrossRef Medline

Palmer MJ, Hull C, Vigh J, von Gersdorff H (2003) Synaptic cleft acidification and modulation of short-term depression by exocytosed protons in retinal bipolar cells. J Neurosci 23:11332-11341. Medline

Price MP, Gong H, Parsons MG, Kundert JR, Reznikov LR, Bernardinelli L, Chaloner K, Buchanan GF, Wemmie JA, Richerson GB, Cassell MD, Welsh MJ (2014) Localization and behaviors in null mice suggest that ASIC1 and ASIC2 modulate responses to aversive stimuli. Genes Brain Behav 13:179-194. CrossRef Medline

Renden R, Taschenberger H, Puente N, Rusakov DA, Duvoisin R, Wang LY,
Lehre KP, von Gersdorff H (2005) Glutamate transporter studies reveal the pruning of metabotropic glutamate receptors and absence of AMPA receptor desensitization at mature calyx of Held synapses. J Neurosci 25:8482-8497. CrossRef Medline

Reyes-Haro D, Müller J, Boresch M, Pivneva T, Benedetti B, Scheller A, Nolte C, Kettenmann H (2010) Neuron-astrocyte interactions in the medial nucleus of the trapezoid body. J Gen Physiol 135:583-594. CrossRef Medline

Shah MJ, Meis S, Munsch T, Pape HC (2001) Modulation by extracellular $\mathrm{pH}$ of low- and high-voltage-activated calcium currents of rat thalamic relay neurons. J Neurophysiol 85:1051-1058. Medline

Trapp S, Lückermann M, Kaila K, Ballanyi K (1996a) Acidosis of hippocampal neurons mediated by a plasmalemmal $\mathrm{Ca}^{2+} / \mathrm{H}^{+}$pump. Neuroreport 7:2000-2004. CrossRef Medline

Trapp S, Lückermann M, Brooks PA, Ballanyi K (1996b) Acidosis of rat dorsal vagal neurons in situ during spontaneous and evoked activity. J Physiol 496:695-710. CrossRef Medline

Traynelis SF, Cull-Candy SG (1991) Pharmacological properties and $\mathrm{H}^{+}$ sensitivity of excitatory amino acid receptor channels in rat cerebellar granule neurones. J Physiol 433:727-763. CrossRef Medline

Urbano FJ, Lino NG, González-Inchauspe C, González LE, Colettis N, Vattino LG, Wunsch AM, Wemmie, JA and. Uchitel OD (2014) Acidsensing ion channels 1a (ASIC1a) inhibit neuromuscular transmission in female mice. Am J Physiol Cell Physiol 306:396-406. CrossRef Medline

Vessey JP, Stratis AK, Daniels BA, Da Silva N, Jonz MG, Lalonde MR, Baldridge WH, Barnes S (2005) Proton-mediated feedback inhibition of presynaptic calcium channels at the cone photoreceptor synapse. J Neurosci 25:4108-4117. CrossRef Medline

Waldmann R, Lazdunski M (1998) H(+)-gated cation channels: neuronal acid sensors in the NaC/DEG family of ion channels. Curr Opin Neurobiol 8:418-424. CrossRef Medline

Waldmann R, Champigny G, Bassilana F, Heurteaux C, Lazdunski M (1997a) A proton-gated cation channel involved in acid-sensing. Nature 386:173-177. CrossRef Medline

Waldmann R, Bassilana F, de Weille J, Champigny G, Heurteaux C, Lazdunski M (1997b) Molecular cloning of a non-inactivating proton-gated $\mathrm{Na}^{+}$channel specific for sensory neurons. J Biol Chem 272:20975-20978. CrossRef Medline

Wemmie JA, Chen J, Askwith CC, Hruska-Hageman AM, Price MP, Nolan BC, Yoder PG, Lamani E, Hoshi T, Freeman JH Jr, Welsh MJ (2002) The acid activated ion channel ASIC contributes to synaptic plasticity, learning, and memory. Neuron 34:463-477. CrossRef Medline

Wemmie JA, Askwith CC, Lamani E, Cassell MD, Freeman JH Jr, Welsh MJ (2003) Acid-sensing ion channel 1 is localized in brain regions with high synaptic density and contributes to fear conditioning. J Neurosci 23: 5496-5502. Medline

Wemmie JA, Price MP, Welsh MJ (2006) Acid-sensing ion channels: advances, questions and therapeutic opportunities. Trends Neurosci 29: 578-586. CrossRef Medline

Wu LJ, Duan B, Mei YD, Gao J, Chen JG, Zhuo M, Xu L, Wu M, Xu TL (2004) Characterization of acid-sensing ion channels in dorsal horn neurons of rat spinal cord. J Biol Chem 279:43716-43724. CrossRef Medline

Xiong ZG, Zhu XM, Chu XP, Minami M, Hey J, Wei WL, MacDonald JF, Wemmie JA, Price MP, Welsh MJ, Simon RP (2004) Neuroprotection in ischemia: blocking calcium-permeable acid-sensing ion channels. Cell 118:687-698. CrossRef Medline

Xiong ZG, Chu XP, Simon RP (2006) $\mathrm{Ca}^{2+}$-permeable acid-sensing ion channels and ischemic brain injury. J Membr Biol 209:59-68. CrossRef Medline

Yermolaieva O, Leonard AS, Schnizler MK, Abboud FM, Welsh MJ (2004) Extracellular acidosis increases neuronal cell calcium by activating acid sensing ion channel 1a. Proc Natl Acad Sci U S A 101:6752-6757. CrossRef Medline

Zha XM (2013) Acid-sensing ion channels: trafficking and synaptic function. Mol Brain 6:1. CrossRef Medline

Ziemann AE, Schnizler MK, Albert GW, Severson MA, Howard MA 3rd, Welsh MJ, Wemmie JA (2008) Seizure termination by acidosis depends on ASICla. Nat Neurosci 11:816-822. CrossRef Medline 